\title{
Immuno-epidemiology and pathophysiology of coronavirus disease 2019 (COVID-19)
}

\author{
Omalla A. Olwenyi ${ }^{1,2} \cdot$ Shetty Ravi Dyavar ${ }^{3} \cdot$ Arpan Acharya $^{1} \cdot$ Anthony T. Podany $^{3} \cdot$ Courtney V. Fletcher $^{3}$. \\ Caroline L. $\mathrm{Ng}^{2} \cdot$ St Patrick Reid ${ }^{2} \cdot$ Siddappa N. Byrareddy ${ }^{1,4,5}$ (I)
}

Received: 31 May 2020 /Revised: 1 August 2020 / Accepted: 6 August 2020 / Published online: 18 August 2020

(C) Springer-Verlag GmbH Germany, part of Springer Nature 2020

\begin{abstract}
Occasional zoonotic viral attacks on immunologically naive populations result in massive death tolls that are capable of threatening human survival. Currently, severe acute respiratory syndrome coronavirus 2 (SARS-CoV-2), the infectious agent that causes coronavirus disease (COVID-19), has spread from its epicenter in Wuhan China to all parts of the globe. Real-time mapping of new infections across the globe has revealed that variable transmission patterns and pathogenicity are associated with differences in SARS-CoV-2 lineages, clades, and strains. Thus, we reviewed how changes in the SARS-CoV-2 genome and its structural architecture affect viral replication, immune evasion, and transmission within different human populations. We also looked at which immune dominant regions of SARS-CoV-2 and other coronaviruses are recognized by Major Histocompatibility Complex (MHC)/Human Leukocyte Antigens (HLA) genes and how this could impact on subsequent disease pathogenesis. Efforts were also placed on understanding immunological changes that occur when exposed individuals either remain asymptomatic or fail to control the virus and later develop systemic complications. Published autopsy studies that reveal alterations in the lung immune microenvironment, morphological, and pathological changes are also explored within the context of the review. Understanding the true correlates of protection and determining how constant virus evolution impacts on host-pathogen interactions could help identify which populations are at high risk and later inform future vaccine and therapeutic interventions.
\end{abstract}

Keywords SARS-COV-2 $\cdot$ COVID-19 $\cdot$ MHC $\cdot$ HLA $\cdot$ Virus evolution $\cdot$ Pathogenesis

\section{Introduction}

In this twenty-first century, the resurgence of novel, lethal, and highly contagious zoonotic viruses to which there is no pre-existing immunity pose a great threat to the survival of mankind as described in Table 1[1-3]. The evolutionary

Siddappa N. Byrareddy

sid.byrareddy@unmc.edu

1 Department of Pharmacology and Experimental Neuroscience, University of Nebraska Medical Center, Omaha, NE, USA

2 Department of Pathology and Microbiology, University of Nebraska Medical Center, Omaha, NE, USA

3 Antiviral Pharmacology Laboratory, Center for Drug Discovery, University of Nebraska Medical Center (UNMC), Omaha, NE, USA

4 Department of Genetics, Cell Biology and Anatomy, University of Nebraska Medical Center, Omaha, NE, USA

5 Department of Biochemistry and Molecular Biology, University of Nebraska Medical Center, Omaha, NE, USA "arms race" between the host and the pathogen surges on and reaches its crescendo when the infectious agent mutates so quickly to successfully evade the host's immune system [4]. This leads to a disease outbreak which could later develop into a pandemic as massive deaths soon ensue. This is followed by the global incapacitation of social, health, economic, and government systems [5-7]. If measures are not put in place to curtail spread of infection, these new emerging biological threats could serve as a catalyst for the total extinction of the human species [8]. Case in point in 1918, a new strain of H1N1 influenza viruses termed the "Spanish flu" led to the deadliest pandemic in human history [9]. This virus infected roughly one-third of the world's population and caused an estimated 50 million deaths worldwide [10].

More recently, novel strains of the usually benign coronaviruses, that routinely cause harmless common colds and have low virulence [11], mutated from their natural reservoir hosts and transitioned towards causing excess infectivity and mortality in humans. Notably, in 2002, Severe Acute Respiratory Syndrome Coronavirus 1 (SARS-CoV-1) 
Table 1 List of zoonotic contagious viruses that cause lethal infections in humans (Source: cdc.gov and ncbi.nlm.nih.gov).

\begin{tabular}{|c|c|c|c|c|c|}
\hline Virus & $\begin{array}{l}\text { Genome (size) } \\
\text { sense }\end{array}$ & Disease & Host & Source of transmission & Symptoms \\
\hline Avian influenza A & $\begin{array}{l}\text { ssRNA (13.5 } \\
\text { kb)-negative }\end{array}$ & Bird flu & $\begin{array}{l}\text { Chicken, ducks, } \\
\text { geese }\end{array}$ & Respiratory droplets/dust & $\begin{array}{l}\text { Fever, cough, and } \\
\text { sore throat }\end{array}$ \\
\hline $\begin{array}{l}\text { Swine origin influenza virus } \\
\text { (S-OIV) }\end{array}$ & $\begin{array}{l}\text { ssRNA (13.5 } \\
\text { kb)-negative }\end{array}$ & Swine flu & Pigs & Respiratory droplets/dust & $\begin{array}{l}\text { Fever, cough, and } \\
\text { lethargy }\end{array}$ \\
\hline West Nile virus (WNV) & $\begin{array}{l}\text { ssRNA (10.9 } \\
\text { kb)-positive }\end{array}$ & $\begin{array}{l}\text { West Nile fever } \\
\text { (WNF) }\end{array}$ & Birds & Mosquito bite & $\begin{array}{l}\text { Fever, } \\
\text { encephalitis, } \\
\text { and meningitis }\end{array}$ \\
\hline Ebola virus & $\begin{array}{l}\text { ssRNA (18.9 } \\
\text { kb)-negative }\end{array}$ & $\begin{array}{l}\text { Ebola virus disease } \\
\text { (EBD) }\end{array}$ & $\begin{array}{l}\text { Bats, non-human } \\
\text { primates }\end{array}$ & $\begin{array}{l}\text { Body fluids, tissues, infected } \\
\text { fruit bats, and non-human } \\
\text { primates }\end{array}$ & $\begin{array}{l}\text { Fever, fatigue, } \\
\text { and diarrhea }\end{array}$ \\
\hline $\begin{array}{l}\text { Severe Acute Respiratory } \\
\text { Syndrome Coronavirus } \\
\text { (SARS-CoV) }\end{array}$ & $\begin{array}{l}\text { ssRNA ( } 29.7 \\
\text { kb)-positive }\end{array}$ & $\begin{array}{l}\text { Severe Acute } \\
\text { Respiratory } \\
\text { Syndrome (SARS) }\end{array}$ & Bats, civet cats & Respiratory droplets & $\begin{array}{l}\text { High fever, } \\
\text { pneumonia, } \\
\text { and diarrhea }\end{array}$ \\
\hline $\begin{array}{l}\text { Middle East respiratory } \\
\text { Syndrome Coronavirus } \\
\text { (MERS-CoV) }\end{array}$ & $\begin{array}{l}\text { ssRNA (30.1 } \\
\text { kb)-positive }\end{array}$ & $\begin{array}{l}\text { Middle East } \\
\text { respiratory } \\
\text { Syndrome (MERS) }\end{array}$ & $\begin{array}{l}\text { Dromedary } \\
\text { camels }\end{array}$ & Respiratory droplets & $\begin{array}{l}\text { High fever, } \\
\text { pneumonia, } \\
\text { and diarrhea }\end{array}$ \\
\hline $\begin{array}{l}\text { Severe Acute Respiratory } \\
\text { Syndrome Coronavirus } 2 \\
\text { (SARS-CoV2) }\end{array}$ & $\begin{array}{l}\text { ssRNA (29.9 } \\
\text { kb)-positive }\end{array}$ & $\begin{array}{l}\text { Coronavirus disease } \\
2019 \text { (COVID-19) }\end{array}$ & Not determined & Respiratory droplets & $\begin{array}{l}\text { High fever, } \\
\text { pneumonia }\end{array}$ \\
\hline
\end{tabular}

$s s R N A$, single-stranded ribonucleic acid; $k b$, kilobase

originated from the Guangdong province in Southern China and was rapidly spread to greater than 8,000 people in over 25 different countries [12]. As a result, over 750 deaths have been observed internationally and a case fatality rate of over $15 \%$ reported in certain populations [13-15]. In 2012, another coronavirus termed Middle East Respiratory Syndrome Coronavirus (MERS-CoV) mutated and jumped the species barrier from camels to humans. This led to infections in 2,496 individuals with $868(35 \%)$ documented fatalities [16]. However, MERS infection events remain localized within the Middle East due to the fact that disease spread relies on a single camel to human vertical transmission event [17].

In December 2019, a third newly emerged coronavirus later named as Severe Acute Respiratory Syndrome Coronavirus 2 (SARS-CoV-2) was detected in Wuhan, the capital city of the Hubei province in China [18]. Following this, SARS-CoV-2 rapidly spread globally with over 17.8 million cases being reported globally on August 1, 2020, accompanied by over 684,096 deaths [19]. In the early stages of the SARS-CoV-2 epidemic in Wuhan, way before any public health interventions had been implemented, the pandemic potential of the virus was evaluated based on its basic reproduction number (R0). The R0 of SARS-CoV-2 was estimated as 3 to 4 implying that each infected case transmitted the virus to roughly 3 to 4 new individuals with doubling occurring every 5 days [20]. Similarly, Sanche et al. estimated the R0 to be likely as high as 5.7 [21], while Li et al. documented an R0 of 2.38 (95\% credible interval (CI): 2.03-2.77) [22]. Following the spread of SARS-CoV-2 to different parts of China, the effective reproduction number $(\mathrm{Re})$ was calculated after the implementation of public health interventions such as city lockdowns, social distancing, and quarantine to mitigate the spread of the virus. All these efforts were undertaken to reduce the R0 to less than 1 in order to eliminate the possibility of a pandemic [23]. The Re was later estimated as 0.98 (95\% CI: $0.83-$ 1.16) during the period of 24 January- 8 February thus highlighting the role of different public health strategies in reducing the global spread of SARS-CoV-2 [22].

\section{Virus evolution due to changes in genomic structure and epidemiology}

Although SARS-CoV-2 has a lower-case fatality rate (currently estimated at 2-4\% as of April 2020 and peaking as high as $10 \%$ in highly populated areas such as New York [24]), far greater deaths have been reported within a short time span in comparison with SARS-CoV-1 and MERS-CoV [25]. This could partly be attributed to the fact that SARS-CoV-2, which has been shown to have close to over $80 \%$ and $50 \%$ sequence homology with SARS-CoV-1 and MERS-CoV respectively [26-28], acquired critical mutations within its genome. This observed difference in genetic composition could possibly favor enhanced infectivity in target cells and accelerate 
disease pathogenesis. Recently, up to 93 mutations have been observed in the entire genome of SARS-CoV-2 with a variable number (6 to 11) of open reading frames (ORF) reported from different geographical regions [29]. Notably, two-thirds of the viral RNA is housed within the first ORF (ORF1a/b) where translation of the two viral polyproteins ppla and pplab together with 16 non-structural proteins (NSP) occurs (21). It has been reported that within SARS-CoV-2 nonstructural protein 2 (NSP2), positive selection pressure facilitated a mutation at amino acid position 321 from an apolar amino acid in in the Bat SARS-like coronavirus to glutamine. This amino acid substitution confers the ability to form stable hydrogen bonds within this endosome-associated protein that could speculatively result in enhanced viral pathogenesis [30].

The other third of the viral genome comprises ORFs that encode structural and accessory proteins together with the $\mathrm{E}$, $\mathrm{M}, \mathrm{S}$, and $\mathrm{N}$ genes that translate envelope (E), matrix (M), spike surface glycoproteins (S), and nucleocapsid (N) structural proteins [31]. Sequence alignments also revealed several mutations within the spike surface glycoprotein in the receptor-binding domain (RDB), which could affect the ability of the virus to attach to the human receptor angiotensin converting enzyme 2 (ACE2). These changes enable SARS-CoV-2 to have a higher binding affinity to human, cat, and ferret ACE2 receptors in comparison with SARS-CoV-1 [18]. Lastly, at the junction of the S1 and S2 subunits of the S protein, SARS-CoV-2 has unique insertions of a polybasic cleavage site (RRAR). This could facilitate effective cleavage by proteases and could modulate virus infectivity. However, the functional roles of RRAR are yet to be fully understood [32].

Intriguingly, the insertion of similar cleavage sites into the junction of S1 and S2 subunits of SARS-CoV-1 has been shown to augment cell to cell fusion [33]. Furthermore, the addition of proline residues to the RRAR cleavage of SARSCoV-2 sites favors the addition of O-linked glycans which could shield critical epitopes of the SARS-CoV-2 spike protein from immune system recognition [34]. Random mutations allow RNA viruses to cross species barriers and adapt to conducive host-pathogen interactions that will maximize viral replication and transmission while minimizing harm to the host $[35,36]$. Current SARS-CoV-2 mutations have led to lineage changes from the original strain that was first detected in Wuhan, China. These SARS-CoV-2 lineages were classified as L (new) and S (ancestral) based on changes in amino acid 84 located in ORF8 whose role in the viral life cycle remains unknown. It was observed that though these lineages coexist concurrently, the L lineage has gradually become highly prevalent in comparison with the S lineage [37]. However, studies are yet to be performed to test whether lineage differences are accompanied with changes in fitness and viral pathogenesis.

Real-time tracking of SARS-CoV-2 reveals that current circulating strains have now spread to all populations across the globe including the Icelandic people [38]. To track the day-to-day evolution of the virus, scientists are encouraged to submit viral sequences to publicly available databases like GISAID (https://www.gisaid.org/CoV2020/) where virus divergence from the original strain from Wuhan is analyzed in real time using the nextstrain platform (https://nextstrain. org/ncov/global) [39]. Based on phylogenetic analysis, three central variants $(\mathrm{A}, \mathrm{B}$, and $\mathrm{C})$ were classified based on differences in amino acids. As of 4 March 2020, variant A and $\mathrm{C}$ were predominantly found outside East Asia, while variant $B$ was predominantly localized within East Asia, perhaps indicating that this variant is immunologically or environmentally adapted to this region.

Sub-clusters, or clades, of A have a unique mutation at nucleotide position T2905C but which encodes a synonymous amino acid with the ancestral genome linked to 4 Chinese individuals from Guangdong who carried the ancestral genome. $\mathrm{B}$ variants differ from A by two-point mutations (the mutation at nucleotide position $\mathrm{T} 8782 \mathrm{C}$ resulting in a synonymous mutation, and a mutation at nucleotide position C28144T resulting in the non-synonymous mutation from a leucine to a serine) [40]. Our nextstrain analysis carried out on 2 May 2020 revealed that the greatest diversity of publicly reported SARS-CoV-2 clades was reported in the Asian continent. Radial phylogenetic trees distanced by time indicate that the predominant clade in Asia and the USA was A2a, while Africa was largely populated with the A2 clade. Europe offered a different visual perspective as the A3 clade was found to be the most common (Fig. 1).

The implications of viral evolution as evidenced by differences in clades acquired as the virus propagates across new host niches on viral pathogenesis are yet to be fully understood. However, a recent report argues that despite social distancing, the differences in deaths observed in the West Coast versus the East Coast of the USA could be driven by cladeassociated mutations of the SARS-CoV-2 spike glycoprotein (31). The B1 clade which predominates the west coast has an aspartic acid (D) at codon 614 of the S protein while the A2a clade on the east coast possesses a glycine $(G)$ at the same position. Phylogenetic analysis shows that the substitution mutation D614G occurred from shifts from the ancestral D residue [41]. It remains hypothesized that this mutation affects a critical region of the heavily glycosylated spike which could account for differences in virulence, viral fusion, and accompanied mortality [42].

\section{Virus structure and replication}

When visualized under an electron microscope, the 3dimensional (3D) appearance of SARS-CoV-2 appears pleomorphic (round or oval) and has a helical nucleocapsid together with spiky protrusions emanating from its surface that give 


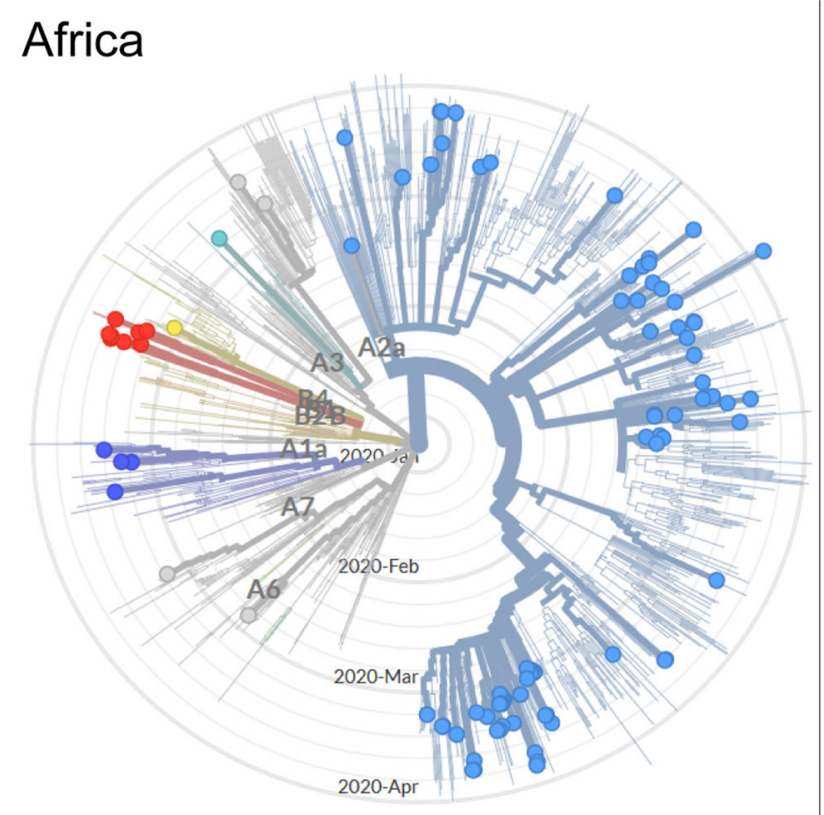

\section{Asia}

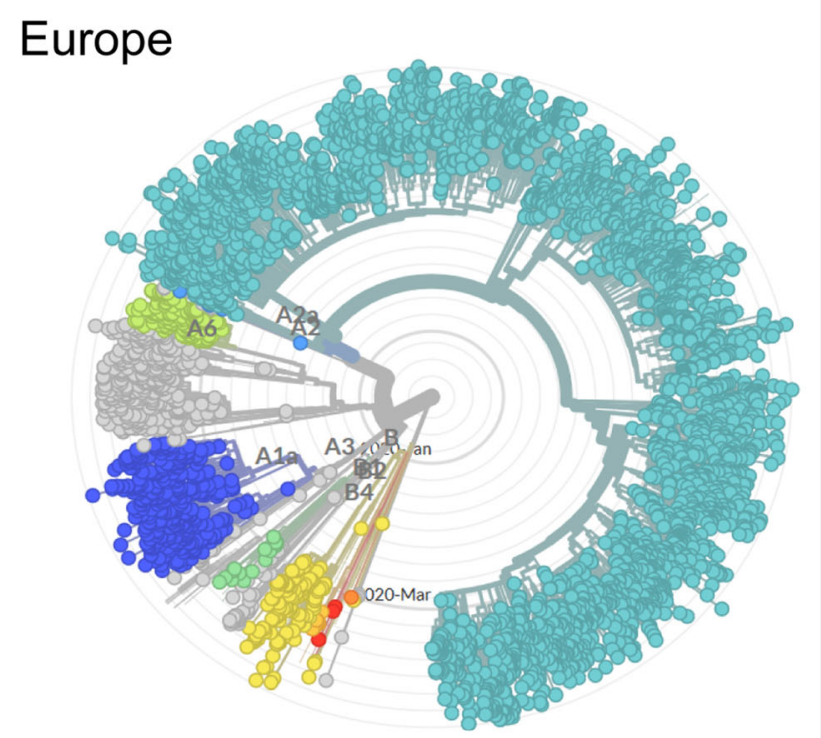

\section{USA}
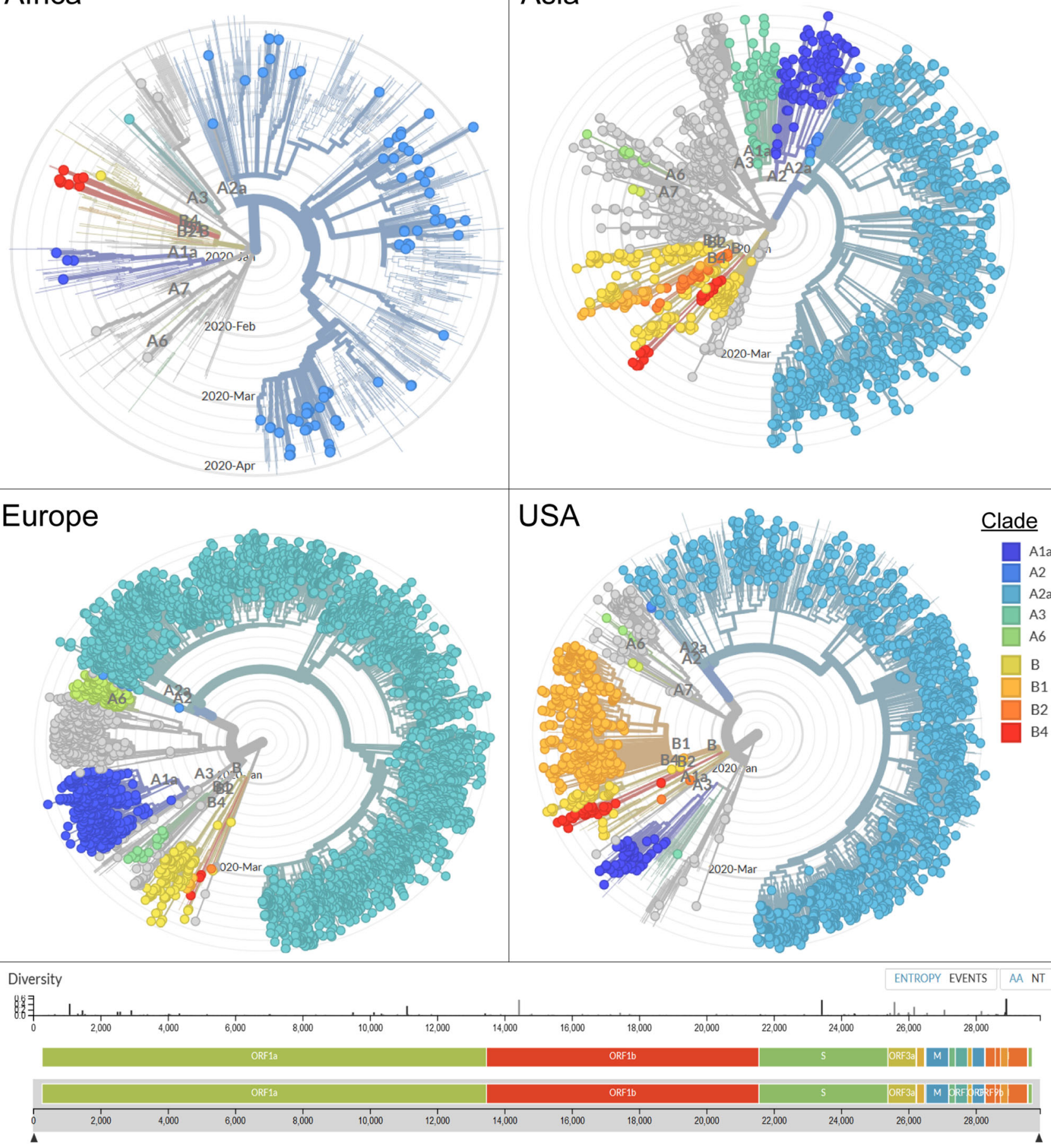

Fig. 1 Phylogenetic analysis of full-length SARS-CoV-2 sequences submitted to Global Initiative on Sharing all Influenza Data (GISAID), (https://www.gisaid.org/CoV2020/). Radial phylogenetic trees were generated using Nextstrain (https://nextstrain.org/ncov) after the SARSCoV-2 global dataset was filtered according to Africa, Asia, Europe, and

it a crown-like appearance [43]. The viral structure comprises an envelope comprising three structural proteins (S, M, and $\mathrm{E}$ ) that encases a single-stranded positive sense 30 kilobase $(\mathrm{kb})$ genome [44] coupled with the structural protein $\mathrm{N}[45,46]$ the USA regions. The branch lengths are distanced by time and individual points colored by Clades (A1a, A2, A2a, A3, A6, B, B1, B2, and B4) with Wuhan-Hu-1/2019 used as a reference. Analysis was carried out on 2 May 2020

(Fig. 2). The S protein is heterotrimeric and projects out of the outer layers of the virus $[47,48]$, while the $\mathrm{N}$ protein binds to RNA to form the nucleocapsid and directs the viral replication cycle. The M protein is the most structurally abundant and is 
crucial to providing shape and stability to the virus. The $\mathrm{E}$ protein is usually least expressed but is critical to maturation of the virus $[49,50]$. As a result of its intricate structure, SARS-CoV-2 has been found to be a relatively stable virus with the ability to survive outside the host for prolonged periods of time. It has been documented to survive up to $3 \mathrm{~h}$ in aerosols [51].

Intriguingly, the virus persisted for $24 \mathrm{~h}$ on cardboard and 2 to 3 days on plastic and stainless steel without any signs of observed decay [52]. Hence, when COVID-19 patients were admitted to a biocontainment unit and in hospital settings, it was documented that besides aerosol transmission, SARS-CoV-2 could be shed and indirectly spread through contamination of objects within the environment like personal items, toiletries, and room surfaces $[53,54]$. Upon inhalation of SARS-CoV-2, the S1 subunit of the $\mathrm{S}$ protein through its RDB domain attaches to the ACE2 receptor expressed on epithelial cells (goblet/secretory cells and ciliated cells) at high density [55] and type II pneumocytes in the lower respiratory tract of humans [56]. ACE2 is also widely distributed in different cells of diverse tissues and organs ranging from the gastrointestinal tract, cardiovascular, urogenital, and central nervous systems $[57,58]$. This accounts for the wide tissue dissemination of SARS-CoV-2, observed in COVID-19 patients, which arises from the availability of several target cells that further propagate infection following inability to resolve lung infection [59].

The attachment of the virus to host target cells could be prevented by pre-existing neutralizing antibodies or cross reacting antibodies from earlier related infections such as SARS-CoV-1 that specifically attach to the SARS-CoV-2 highly variable RDB domain of the $\mathrm{S} 1$ subunit $[45,46]$. Post attachment, the cellular serine protease termed as the cell surface-associated transmembrane protease serine 2 (TMPRSS2) cleaves the S protein into S1 and S2 [60]. This separation activates the fusion of the viral envelope with the host cell resulting in the release of the viral nucleocapsid into the cytoplasm [61]. Upon deposition of the viral genome into the host cell, direct translation of ORF1a/b genes begins resulting in the generation of polyproteins ppla and pp $1 \mathrm{ab}$ that are further processed to form non-structural proteins [62].

These non-structural proteins form interconnected double membrane replication transcription complexes (RTC) in which subgenomic RNAs are encoded to generate accessory and structural proteins $[63,64]$. These replication compartments help concentrate viral and host transcription factors and offer a "safe haven" for protection of the virus from the hosts' exonucleases and other host innate immune responses [65]. The newly generated genomic RNA, nucleocapsid proteins, and envelope glycoproteins then navigate and traverse the endoplasmic reticulum and Golgi network where they
Fig. 2 Key structural proteins of severe acute respiratory syndrome coronavirus 2 (SARS-CoV-2) that include the spike surface glycoprotein (S), membrane protein (M), RNA attached to nucleocapsid protein $(\mathrm{N})$ and envelope protein $(\mathrm{E})$.

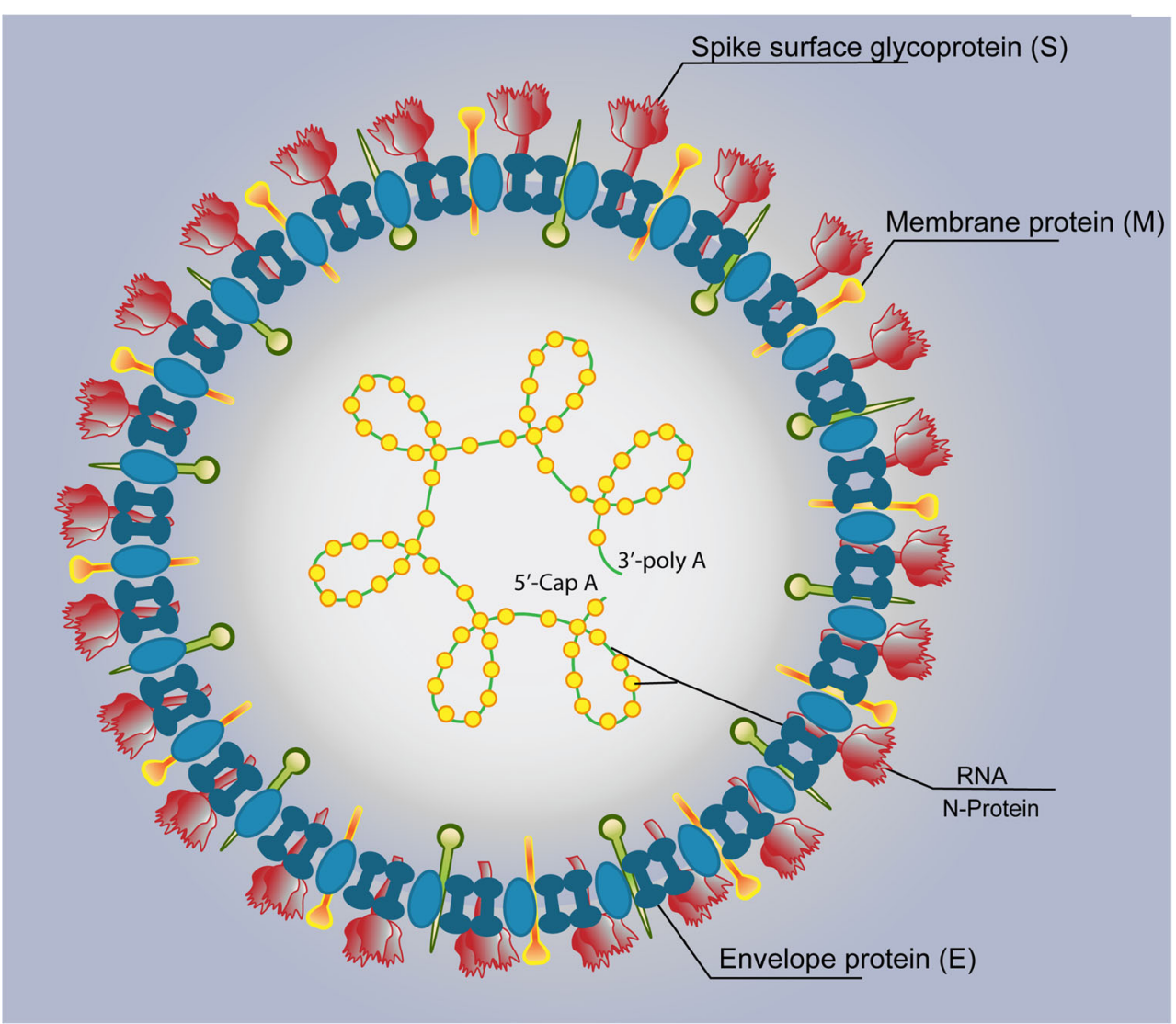


assemble and form viral particles which later fuse with the plasma membrane and hijack the lipid bi-layer to form progeny viral particles [66].

To maximize viral replication, coronaviruses utilize a pathogenic factor, non-structural protein 1 (nsp1), which promotes the endonucleolytic cleavage of the hosts RNA and blocks the translation any remaining host RNA. This takeover of the host genomic machinery ensures maximum generation of viral progeny at the expense of the host's needs $[66,67]$. In addition, nsp1 inhibits the host expression of type 1 interferons thus offering a milieu that favors virus replication [68]. This is attributed to the fact that these cytokines favors optimal stimulation of $\mathrm{T}$ cell responses by enhancing antigen presentation through increased expression of major histocompatibility complex 1 (MHC 1) on various cells [69]. Similarly, the highly conserved nsp16 facilitates enhanced virus replication by facilitating virus evasion from recognition from the hosts pattern recognition receptor (PRR) melanoma differentiationassociated protein 5 (MDA5) and as a result downregulates the type 1 interferon response [70]. Comprehensive proteomic analysis of SARS-CoV-2 revealed that SARS-CoV-2 proteins such as Orf6 and nsp13 also target the host interferon signaling pathways. Orf3a and NSP9 of SARS-CoV-2 also antagonize host $\mathrm{E} 3$ ubiquitin ligases that lead to the dysregulation of host antiviral signaling [71-73].

\section{Host genetics: influence of HLA alleles on susceptibility and resistance to SARS-CoV-1, MERS-CoV, and SARS-CoV-2 infections}

During viral infections, effective antiviral immunity is fostered through cooperative interactions between the host's specific innate and adaptive immune responses. Antigenpresenting cells recognize and process viral antigens into smaller peptides that are later attached onto major histocompatibility complex (MHC) class I/II molecules or Human Leukocyte Antigen (HLA) alleles [74]. Specific peptide and HLA combinations are then recognized by $\mathrm{T}$ cells (CD4 T cells and CD8+/ cytotoxic T cells (CTLs)) of the adaptive immune system. This leads to the respective CD4+ $\mathrm{T}$ cell orchestration of overall immune cell function through cytokine secretion and CTL killing/ clearance of virus-infected cells.

The interaction of $\mathrm{T}$ cell receptors (TCRs) with a unique specific set of HLAs determines the efficacy to induce SARS$\mathrm{CoV}-2$ specific immune responses that may confer protection or predispose the host to infection [75, 76]. SARS-CoV-1 structural proteins such as $\mathrm{S}, \mathrm{M}$, and $\mathrm{N}$ are more immunogenic in comparison with NSPs. SARS-CoV-1 N protein's 219 to 235 residues comprise HLA-A*0201 restricted epitopes [77, 78]. Position 331 to 365 residues also consist of HLA-A*2402 restricted CTL epitopes that are capable of inducing memory $\mathrm{T}$ cell responses [79-81]. Notably, HLA-Cw1502 and DR0301 confer resistance to SARS-CoV-1 infection [82]. Alternatively, MHC class I HLA-B*-4601, HLA-B*-0703, HLA-Cw* 0801 and MHC class II HLA-DRB1*1202 have previously been associated with increased susceptibility to SARS-CoV-1 [83-85], while MHC class II HLADRB1*11:01 and DQB1*02:02 have been found to exacerbate susceptibility to MERS-CoV [86].

Recently, Nguyen et al. conducted an elaborate in silico analysis of the binding affinities between SARS-CoV-2 peptides and various MHC class I molecules that spanned 145 HLA-A, -B, and -C genotypes. They predicted that HLA$B * 46: 01$ bound to a fewer number of viral peptide antigens and as a result postulated that individuals who lack this allele have an increased risk of vulnerability to SARS-CoV2 infection. On the other hand, HLA-B*15:03 bound to a large number of SARS-CoV-2 peptides that were highly conserved within various human coronaviruses and as such were hypothesized to induce cross-protective T cell-based immunity [87]. Interestingly, Grifoni and Kiyotani et al. also reported extensive $\mathrm{B}$ cell and $\mathrm{T}$ cell epitope sequence similarity between SARS-CoV-2 and SARS-CoV-1 [26, 88]. This further emphasizes the possibility of the existence of cross-reactive protective immune responses that could be inferred from memory responses generated from earlier exposures to other related coronaviruses.

\section{Immune evasion and subsequent disease pathogenesis}

The innate immune response is the first line of defense against invading microorganisms. The host's innate immune response uses a wide variety of PRRs ranging from toll-like receptors, RIG-I like receptors such as MDA5, C-type lectin receptors (CLRs), and nucleotide binding and oligomerization domain (NOD)-like receptors to recognize a variety of highly conserved residues on SARS-CoV-2 [89]. Unsurprisingly, SARS-CoV-2 targets cells such as nasal epithelial cells found in the respiratory tract that highly express viral entry factors such as ACE2 and TMPRSS2 and are enriched with a diversity of innate immune genes [90]. Nasal epithelial cells highly express viral entry factors such as ACE2 and TMPRSS2, but are also enriched with a diversity of innate immune genes [90].

During virus attachment, SARS-CoV-2-specific or crossneutralizing antibodies from SARS-CoV-1 [45, 91, 92] could inactivate the virus [93], prevent viral attachment to target cells [94], and perform opsonization for clearance by the complement pathway and $\mathrm{Fc}$ receptor-mediated phagocytosis of alveolar macrophages [95, 96]. Upon successful infection of lung epithelial cells and subsequent viral recognition, the 
release of type I interferons is immediately evoked from the epithelial cells. Dendritic cells and macrophages within the lung microenvironment secrete type I interferons upon recognition of the virus through their PRRs. Collectively, this sustains a potent antiviral response by inhibiting virus replication, ensuring efficient antigen presentation of peptides to $\mathrm{CD} 4^{+}$ and $\mathrm{CD}^{+} \mathrm{T}$ cells and efficiently promote specific adaptive $\mathrm{T}$ cell responses and cytotoxicity of $\mathrm{CD} 8^{+} \mathrm{T}$ and natural killer (NK) cells [97-100].

Recent transcriptomic data showed that robust $\mathrm{CD} 8^{+} \mathrm{T}$ cell responses accompanied with clonal expansion were observed in individuals who only develop mild disease symptoms and those who cleared SARS-CoV-2 from the lungs [101]. In mild and moderate cases, the clearing of COVID-19 infection has been reported to occur within 10 days following the onset of symptoms which include shortness of breath, fever, dry cough, and dyspnea [102-104]. Following this brief inflammatory phase, the alveolar macrophages clear all debris arising from apoptotic virus-infected cells, limit the buildup of surfactant, and resolve inflammation within the lung microenvironment by secreting cytokines like IL-10, transforming growth factor beta $(T G F-\beta)$ and increased expression of checkpoint inhibitors such as CD200 that strive to return this niche to its conventional anti-inflammatory state [105]. Together, this ensures optimal tissue remodeling, maintenance of the lung barrier, and clearance of airways where efficient gaseous exchange is fostered within the air sacs following the brief inflammation phase [106-108], (Fig. 3).

Alternatively, the virus is capable of overpowering all barricades set up by the host immune system and later establishing successful infection within the lung microenvironment [109]. This is followed by dissemination of infection into other tissues and organs where the virus leaves a devastating trail of gross systemic pathology in its wake $[110,111]$. To achieve this, SARS-CoV-2 escapes detection from any neutralization antibodies present or cross-neutralizing antibodies generated from earlier infection with SARS-CoV-1. In worst-case scenarios, SARS-CoV-1 cross-neutralizing antibodies could lead to antibody-dependent enhancement (ADE) [112]. SARS$\mathrm{CoV}-2$ non-neutralizing antibodies that bind to regions of the $\mathrm{S}$ protein outside the RDB domain have greater chances of generating ADE responses [113].

During ADE, antibodies attached to non-neutralized virus gain entry into macrophages through $\mathrm{Fc}$ receptors $(\mathrm{FcR})$ and reprogram them to secrete proinflammatory cytokines that sustain viral pathogenesis [114]. SARS-CoV-2 also distorts type I IFN signaling leading to delayed secretion of type I interferons. This results in augmented virus replication which reaches its maximum 5-6 days after the onset of symptoms [115]. The immense replication of the virus within epithelial cells and enhanced virus entry into alveolar macrophages leads to increased cell death by pyroptosis as the levels of cytokines such as IL-1 $\beta$ and IL6 that drive the formation of the inflammasome cascade are elevated $[116,117]$. As a result, a massive loss of alveolar macrophage frequencies mirrored with an enrichment of inflammatory Ficolin-1+ $\left(\mathrm{FCN}^{+}\right)$macrophages within the lung bronchoalveolar occurs [101].

These inflammatory macrophages together with other dysregulated antigen-presenting cells (APCs) then forward processed peptides to the adaptive immune system in a defective manner that leads to impaired virus specific $\mathrm{T}$ cell responses. Hence, while high frequencies of $\mathrm{T}$ cells that secrete high levels of the TH1/ IL-17 family of cytokines that are crucial for viral eradication have been noticed [118], these cells express high levels of hyperactivated (CD38/Human Leukocyte AntigenDR (HLA-DR)) and exhaustion markers such as the programmed death ligand 1 (PD-1)) [119]. As a result, this hyperactivated state dampens host-specific $\mathrm{T}$ cell responses and further impairs $\mathrm{T}$ cell functionality [120-122]. In addition, $\mathrm{CD}^{+} \mathrm{T}$ cells from individuals who develop severe symptoms of COVID-19 have been reported to have defective IFN $\gamma$ secretion and as such poorly orchestrate help to other cell subsets [122].

Lastly, the N protein of SARS-CoV-2 binds to mannosebinding lectin (MBL) leading to the activation of the alternative complement pathway [123]. This leads to the deposition of anaphylatoxins such as $\mathrm{C} 5 \mathrm{a}$ that serve as chemo attractants for other inflammatory cells such as monocytes, neutrophils, and eosinophils through the secretion of diverse inflammatory cytokines and chemokines [123, 124]. This partly contributes to the ongoing cytokine storm as the excessive unchecked production of cytokines such as IL-6, IL-10, GMCSF, IL$1 \beta$, and TNF- $\alpha$ ensues $[125,126]$. This uncontrolled release of inflammatory cytokines results in both local and systemic pathology. Within the lungs, injury occurs to the lung endothelium, epithelial cells, and bronchoalveolar capillaries leading to elevated vascular permeability, disseminated intravascular coagulation, focal demarcation of hemorrhages, and proteinaceous exudates within alveolar spaces [127-129]. Shortness of breath arises from poor oxygen supply/ diffusion and low efficiency of gaseous exchange that gives the lungs an appearance of bi-lateral ground-glass opacity during computed tomography (CT) scans [130]. Systemic effects of COVID-19 also include damage to the central nervous system, which presents with acute hemorrhagic necrotizing encephalopathy [131], altered mental status, and seizures [132]. As a result of the cytokine storm, multiple organ failure that is characterized by clotting and elevated D-dimer levels within the cardiovascular system occurs. Acute kidney injury also takes place alongside necrotic destruction of the lymph nodes and spleen [133-135], (Fig. 4).

\section{Conclusions and future perspectives}

This review has focused on both virus evolution and transmission patterns, changes in virus structure that enhance 


\section{Human respiratory system}

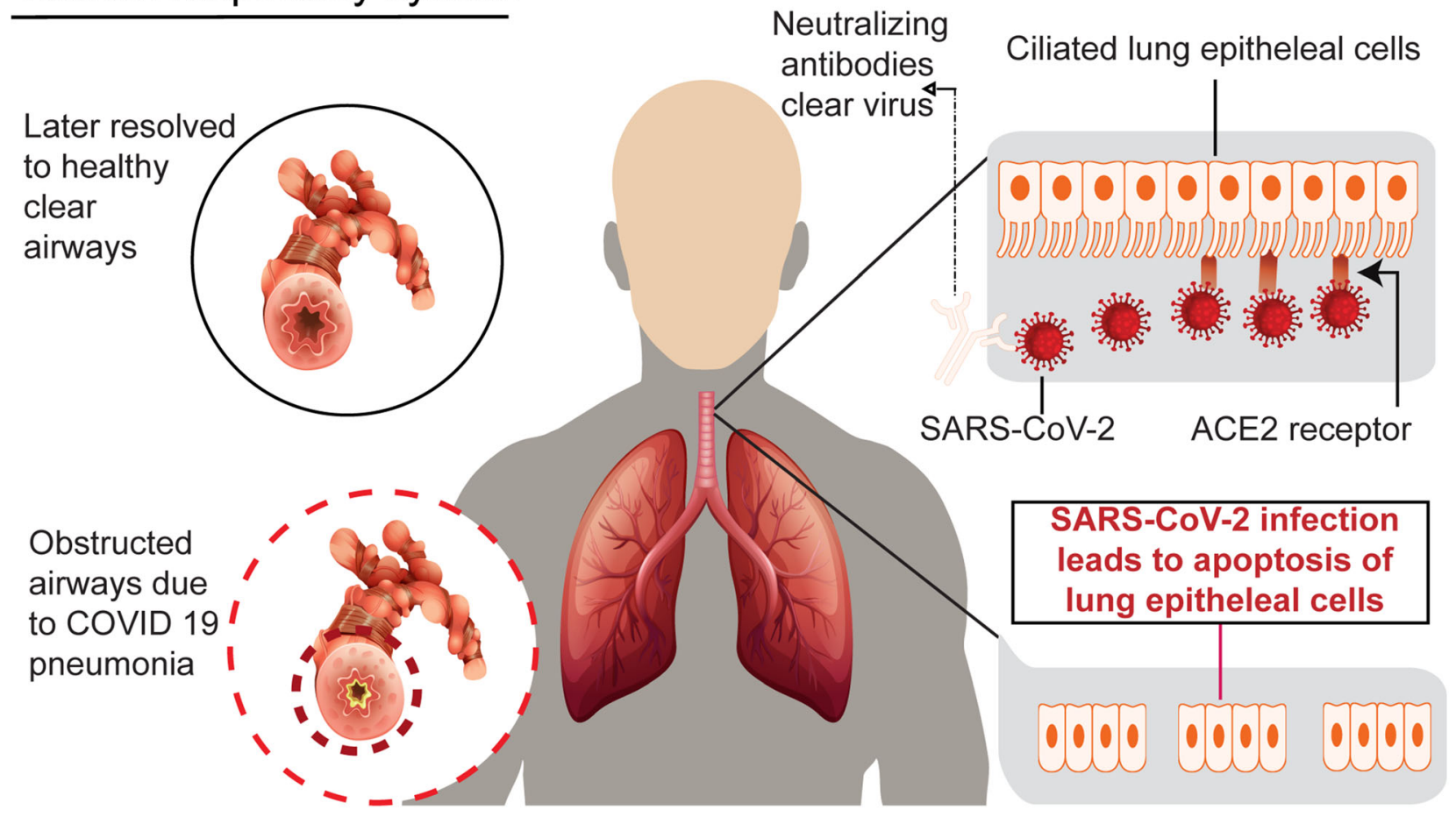

\section{Efficient alveolus gaseous exchange}

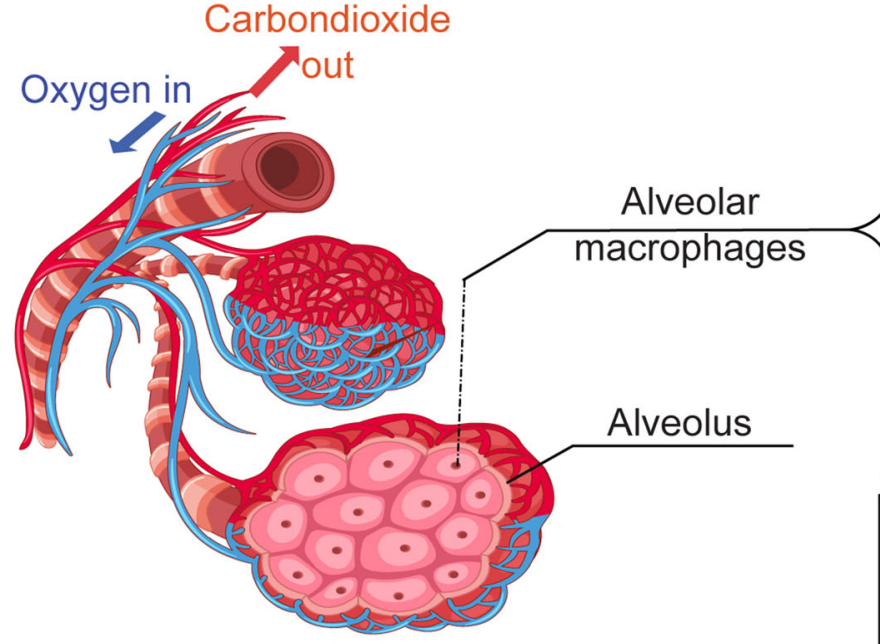

Fig. 3 Immunological events that occur in individuals who develop asymptomatic/mild to moderate symptoms of COVID-19 following exposure to SARS-CoV-2. Infection can be cleared by neutralizing antibodies (nabs). Upon recognition of foreign invaders via pattern recognition receptors (PRRs), macrophages secrete type I interferons that lead to an antiviral state. In addition, these macrophages phagocytose virus-infected

pathogenesis, and the immune evasion strategies that are used by the virus to evade immune detection. Except for the brief sidenote on targeting macrophages as reserviors/carriers for SARS-CoV-2, we chose not to delve into therapeutic options

\section{Alveolar Macrophages \\ - Timely release of Type 1 Interferon \\ - Phagocytose virus infected cells \\ - Clear surfactant and accumulated debris \\ - Efficient antigen presentation and good T cell help \\ - Resolve inflammation and repair alveolar barrier

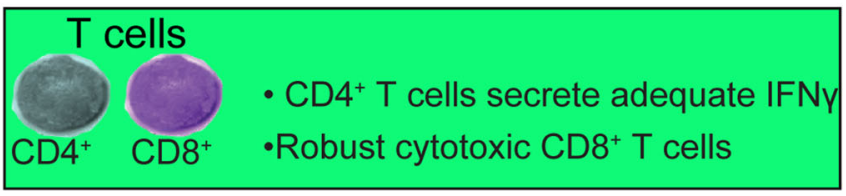

cells that could have been opsonized by the nabs, carry out efficient antigen presentation to T cells, clear all the debris in the lungs, and resolve inflammation. As a result, highly functional $\mathrm{T}$ cells $(\mathrm{CD} 4+\mathrm{T}$ cells expressing high levels of IFN $\gamma$ and increased CD8+ T cell cytotoxicity) are obtained.

that could be utilized to eradicate the pathogen as these approaches have been elaborately discussed in separate reviews $[71,109]$. Indeed, comprehensive analysis of several tissues revealed that macrophages play a crucial role in redirecting 
inflammation and driving the pathogenesis of SARS-CoV-2 [136]. It has recently been shown that $\mathrm{CD} 169^{+}$tissue resident macrophages in the lymph nodes and spleens could serve as viral carriers of SARS-CoV-2 [137]. Similar to what is

\section{Human respiratory system}

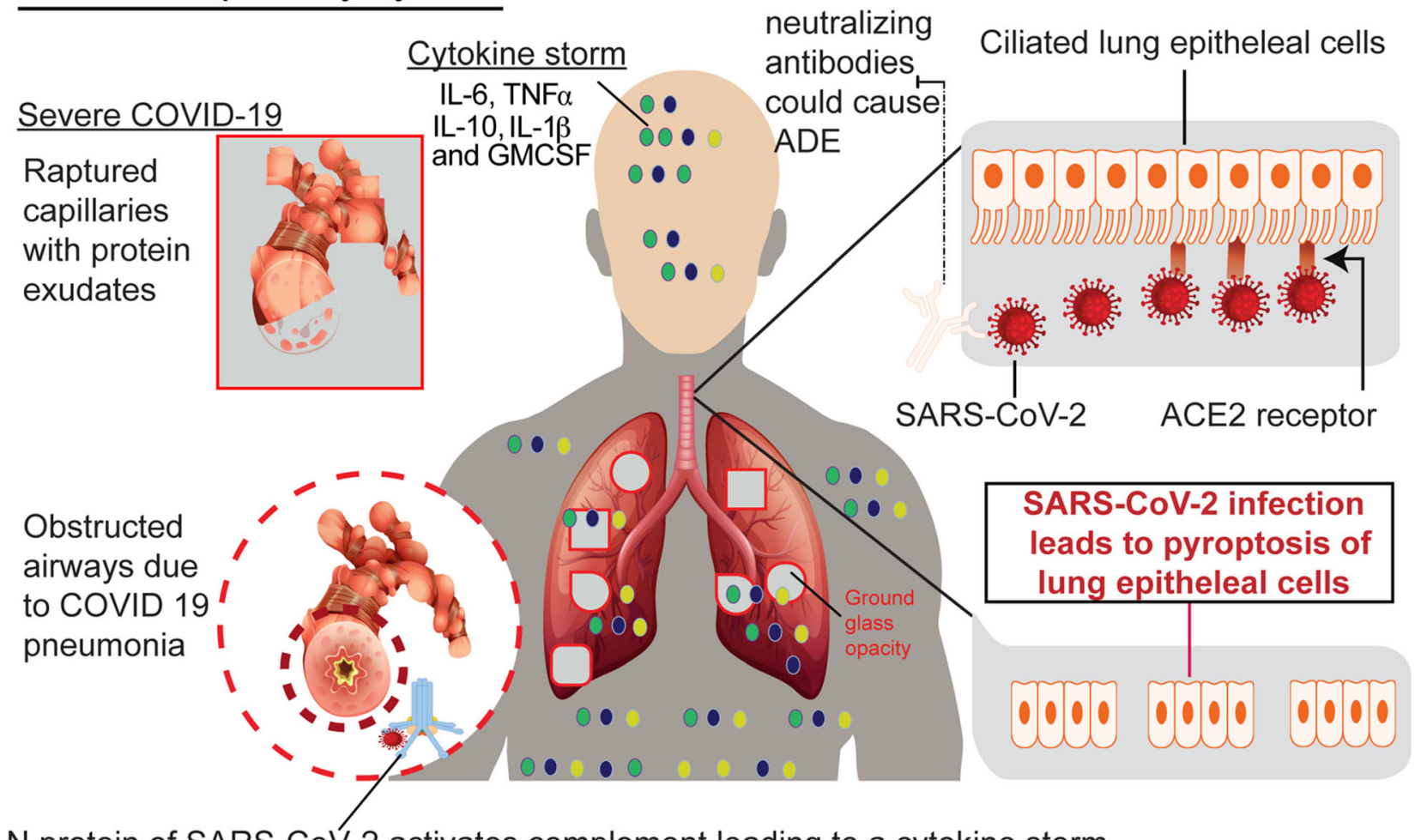

$\mathrm{N}$ protein of SARS-CoV-2 activates complement leading to a cytokine storm

\section{Defective Alveolus gaseous exchange}

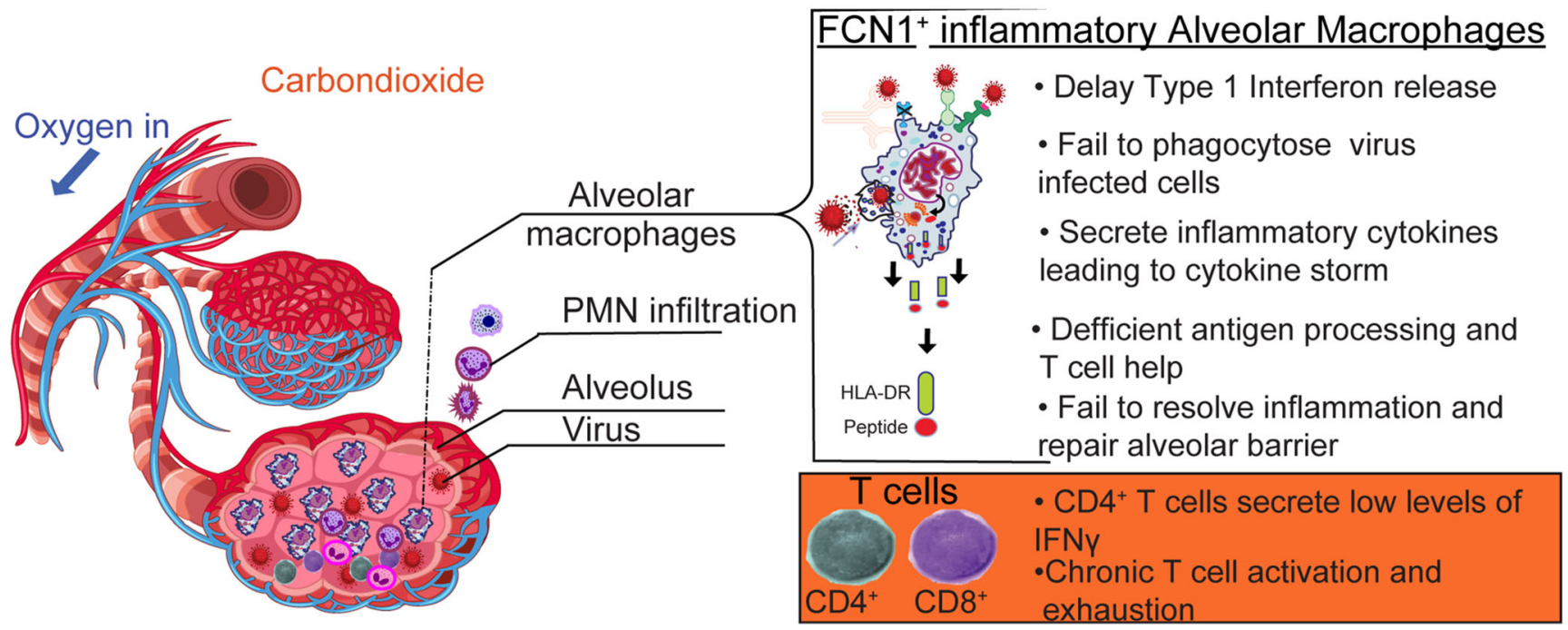

Fig 4 Immunological events that lead to severe COVID-19. SARS-CoV2 evades detection by neutralizing antibodies (nabs). Present non-nabs could contribute to the severity of pathogenesis by causing antibodydependent enhancement (ADE). Following macrophage detection of the virus, delays in secretion of type 1 interferons avoid antiviral state hence favoring increased viral replication. In addition, macrophage function is dysregulated as evidenced by the failure to resolve inflammation within the lungs, inadequate repairs of the alveolar barrier, damage to the alveolar capillary networks, and increased buildup of debris leads to poor oxygen saturation as demonstrated by bi-lateral ground-glass opacity. In addition, the depletion of alveolar macrophages followed by subsequent enrichment of inflammatory Ficolin- $1+\left(\mathrm{FCN}^{+}\right)$macrophages, infiltration of polymorphonuclear neutrophils (PMNs) followed by activation of complement pathways lead to exaggerated production of inflammatory cytokines that later sustains a cytokine storm, and fuels systemic pathology. 
currently being done to develop long-acting HIV therapy [138-140], repurposing drugs to directly target diverse myeloid carriers such as macrophages may not only lower viral loads but also ensure the timely dissemination of pro-drugs into diverse tissues as these cells could act as drug carriers.

In addition, the intricate role of the stimulation of interferons (IFN) such as IFN $\alpha$ and IFN $\beta$ in delaying or exacerbating SARS-CoV-2 is yet to be fully delineated. The five transmembrane PRR referred to as the stimulator of interferon response genes (STING) is expressed in the endoplasmic reticulum of lung alveolar epithelial cells, endothelial cells, and splenocytes. STING senses PAMPs such as damaged DNA, viral nucleic acid sequences, or intermediate products resulting in the stimulation of type 1 IFN responses [141]. Early in infection, SARS-CoV-1 releases viral papain-likeproteases, found within the nsp3 and nsp 16 proteins that inhibit STING's downstream IFN secretion [142, 143]. There is no evidence of SARS-CoV-2 dysregulating STING function. However, Berthelot et al. suggest that extensive inflammatory damage associated with severe COVID-19 provides elevated amounts of damaged DNA leading to extensive hyperactivation of STING [141]. This could possibly lead to elevated expression of IFNs that could facilitate the continued infiltration of inflammatory cells such as neutrophils into the lungs and sustain the cytokine storm. Intriguingly, in bats, which are placental mammals that coexist with several coronaviruses and serve as natural reserviors [144], STING polymorphisims ensure lower IFN secretion that later contributes towards reduced immune pathogenesis [145]. Collectively, these observations highlight the need for further investigation of how STING polymorphisims could affect SARS-CoV-2 immune pathogenesis.

Tracing transmission patterns and evolutionary genomic changes in SARS-CoV-2 while factoring alterations in host immunity could accurately inform epidemiological models that offer reliable predictions on when the number of COVID-19 infections will decrease [146]. Additional studies are required to validate observations that the extent of pathogenicity could vary with different L and S SARS-CoV-2 lineages. Further investigations are also required to crossvalidate the differences in pathogenesis observed in the predominant clades of the US west versus east coasts [41].

Recently, Korber et al. provided evidence that the predominant D614 mutation in the SARS-CoV-2 Spike protein is gradually being replaced by G614 mutations in diverse populations worldwide. This newly predominant mutant was shown to have acquired a fitness advantage highlighted by an increased replication capacity that was demonstrated by elevated viral loads. Infection with this variant was also demonstrated by reduced disease severity as measured by extended hospitalization. Lastly, it was also shown that G614 pseudo virions were more prone to neutralization antibodies [147]. Collectively, these results show that within an evolutionary context, SARS-CoV-2 is slowly transitioning into variants that favor suitable host-pathogen interactions [148]. By ensuring enhanced virus replication within a host while limiting host death, the predomianant G614 mutant guarantees better adaptation to the human host in comparisons to the original Wuhan D614 variant. Experiments are currently being conducted to evaluate whether these observed increases in infectivity have any visible effects on transmission dynamics within diverse populations [149]. In addition, an in-depth SARSCoV-2 report by Kupferschmidt argues that although the G614 mutant easily infects a lab cell line, observations may not be reproducible within the diverse cell types found within a human host [149].

Though datasets such as that of GISAID may not reflect the true dynamism of transmission in resourcelimited regions such as Africa, routine evaluation of mutations that occur in these areas is needed to inform the scientific community about how SARS-CoV-2 adapts to regions with endemic tropical co-infections such as HIV, malaria, helminths, and TB [150-152]. There is a need to carry out further research focused on the dynamics of SARS-CoV-2 spread in African Americans as these individuals have been shown to have higher incidences of COVID-19 [153, 154]. Additional studies are warranted to dissect which MHC/HLA-DR polymorphisms across different populations are associated with protection or susceptibility across different populations.

Future studies will also be needed to evaluate whether immunity developed following exposure to SARS-CoV-2 is capable of protection from future encounters with the pathogen [155]. Testing whether repeated exposures boost immunity [156] and evaluating protection from future infection with different SARS-CoV-2 clades without development of deleterious immune responses such as $\mathrm{ADE}$ could also inform strategies to design future vaccines. Lastly, extensive research should also be carried out to understand changes that occur in asymptomatic individuals as these persons have been reported to enable the rapid spread of COVID-19 and sustain transmission patterns of the global epidemic [22].

Acknowledgements This review was written as part of the requirements for the PAMM 890 MOLECULAR BIOL VIRUSES course conducted at the University of Nebraska Medical Center. All graphics were drawn as part of training for the concurrent Adobe training courses conducted in the Pathology and Experimental Neuroscience Department held by Robin Taylor (the lung graphics (Fig. 3 and Fig. 4) were redrawn based on free vector models found on: https://www.vecteezy.com).

Funding information The authors received funding from the National Institutes of Health: RO1 AI124965-01 and UM1AI06701 (to CVF) and UNMC Nebraska Neuroscience Alliance COVID-19 Rapid Response grant and Nebraska Research Alliance (NRI) Collaborative award to SRD. This work was also supported, in part, by, P30MH062261, Frances E. Lageschulte and Evelyn B. Weese New Frontiers in Medical Research Fund to SNB. 


\section{Compliance with ethical standards}

Conflicts of interest The authors declare that they have no conflict of interest.

\section{References}

1. Mnookin S (2011) The panic virus: a true story of medicine, science, and fear. Simon and Schuster

2. Galloway SE, Petzing SR, Young CG (2015) Reassessing biological threats: implications for cooperative mitigation strategies. Front Public Health 3(251). https://doi.org/10.3389/fpubh.2015. 00251

3. Dawood AA (2020) Mutated COVID-19 may foretell a great risk for mankind in the future. New Microbes New Infect 35:100673

4. Rouzine IM, Rozhnova G (2018) Antigenic evolution of viruses in host populations. PLoS Pathog 14(9):e1007291

5. Remuzzi A, Remuzzi G (2020) COVID-19 and Italy: what next? Lancet

6. Organization WH (2020) Coronavirus disease 2019 (COVID-19): situation report, 70

7. Anderson RM, Heesterbeek H, Klinkenberg D, Hollingsworth TD (2020) How will country-based mitigation measures influence the course of the COVID-19 epidemic? Lancet 395(10228):931-934

8. Wolff H, Greenwood AD (2010) Did viral disease of humans wipe out the Neandertals? Med Hypotheses 75(1):99-105

9. Shortridge KF (1999) The 1918 'Spanish' flu: pearls from swine? Nat Med 5(4):384-385

10. Trilla A, Trilla G, Daer C (2008) The 1918 "Spanish flu" in Spain. Clin Infect Dis 47(5):668-673

11. Greenberg SB (2016) Update on human rhinovirus and coronavirus infections. In: Seminars in respiratory and critical care medicine. vol 04. Thieme Medical Publishers, pp 555-571

12. Zhong NS, Zheng BJ, Li YM, Poon XZH, Chan KH, Li PH, Tan SY, Chang Q, Xie JP, Liu XQ, Xu J, Li DX, Yuen KY, Peiris GY (2003) Epidemiology and cause of severe acute respiratory syndrome (SARS) in Guangdong, People's Republic of China, in February, 2003. Lancet (London, England) 362(9393):1353-1358

13. Martina BEE, Haagmans BL, Kuiken T, Fouchier RAM, Rimmelzwaan GF, van Amerongen G, Peiris JSM, Lim W, Osterhaus ADME (2003) SARS virus infection of cats and ferrets. Nature 425(6961):915-915

14. Cao W-C, de Vlas SJ, Richardus JH (2011) The severe acute respiratory syndrome epidemic in mainland China dissected. Infect Dis Rep 3(1):e2-e2

15. Hung LS (2003) The SARS epidemic in Hong Kong: what lessons have we learned? J R Soc Med 96(8):374-378

16. Meo S, Alhowikan A, Al-Khlaiwi T, Meo I, Halepoto D, Iqbal M, Usmani A, Hajjar W, Ahmed N (2020) Novel coronavirus 2019nCoV: prevalence, biological and clinical characteristics comparison with SARS-CoV and MERS-CoV. Eur Rev Med Pharmacol Sci 24(4):2012-2019

17. Arabi YM, Balkhy HH, Hayden FG, Bouchama A, Luke T, Baillie JK, Al-Omari A, Hajeer AH, Senga M, Denison MR, NguyenVan-Tam JS, Shindo N, Bermingham A, Chappell JD, Van Kerkhove MD, Fowler RA (2017) Middle East Respiratory Syndrome. N Engl J Med 376(6):584-594

18. Wan Y, Shang J, Graham R, Baric RS, Li F (2020) Receptor recognition by the novel coronavirus from Wuhan: an analysis based on decade-long structural studies of SARS coronavirus. J Virol 94(7):e00127-e00120
19. (WHO) WHO (2020) Coronavirus disease (COVID-19) Situation Report - 186 https:/www.who.int/emergencies/diseases/novelcoronavirus-2019/situation-reports. Accessed 7/24/2020 2020

20. Pan A, Liu L, Wang C, Guo H, Hao X, Wang Q, Huang J, He N, Yu H, Lin X, Wei S, Wu T (2020) Association of public health interventions with the epidemiology of the COVID-19 outbreak in Wuhan, China. JAMA 323(19):1915-1923

21. Sanche S, Lin YT, Xu C, Romero-Severson E, Hengartner N, Ke R (2020) Early release-high contagiousness and rapid spread of severe acute respiratory syndrome coronavirus 2

22. Li R, Pei S, Chen B, Song Y, Zhang T, Yang W, Shaman J (2020) Substantial undocumented infection facilitates the rapid dissemination of novel coronavirus (SARS-CoV-2). Science 368(6490): 489-493

23. Li Q, Guan X, Wu P, Wang X, Zhou L, Tong Y, Ren R, Leung KSM, Lau EHY, Wong JY, Xing X, Xiang N, Wu Y, Li C, Chen Q, Li D, Liu T, Zhao J, Liu M, Tu W, Chen C, Jin L, Yang R, Wang Q, Zhou S, Wang R, Liu H, Luo Y, Liu Y, Shao G, Li H, Tao Z, Yang Y, Deng Z, Liu B, Ma Z, Zhang Y, Shi G, Lam TTY, Wu JT, Gao GF, Cowling BJ, Yang B, Leung GM, Feng Z (2020) Early transmission dynamics in Wuhan, China, of novel coronavirus-infected pneumonia. N Engl J Med 382(13):11991207

24. Iype E, Gulati S (2020) Understanding the asymmetric spread and case fatality rate (CFR) for COVID-19 among countries. medRxiv:2020.2004.2021.20073791. https://doi.org/10.1101/ 2020.04.21.20073791

25. Giwa A, Desai A, Duca A (2020) Novel 2019 coronavirus SARSCoV-2 (COVID-19): an overview for emergency clinicians. Pediatr Emerg Med Pract 17(5):1-24

26. Grifoni A, Sidney J, Zhang Y, Scheuermann RH, Peters B, Sette A (2020) A sequence homology and bioinformatic approach can predict candidate targets for immune responses to SARS-CoV-2. Cell Host Microbe 27(4):671-680.e672

27. Wu A, Peng Y, Huang B, Ding X, Wang X, Niu P, Meng J, Zhu Z, Zhang Z, Wang J (2020) Genome composition and divergence of the novel coronavirus (2019-nCoV) originating in China. Cell Host Microbe 27:325-328

28. Chan JF-W, Kok K-H, Zhu Z, Chu H, To KK-W, Yuan S, Yuen K-Y (2020) Genomic characterization of the 2019 novel humanpathogenic coronavirus isolated from a patient with atypical pneumonia after visiting Wuhan. Emerg Microbes Infect 9(1):221-236

29. Phan T (2020) Genetic diversity and evolution of SARS-CoV-2. Infect Genet Evol 81:104260

30. Angeletti S, Benvenuto D, Bianchi M, Giovanetti M, Pascarella S, Ciccozzi M (2020) COVID-2019: the role of the nsp2 and nsp3 in its pathogenesis. J Med Virol 92:584-588

31. Wang Y-T, Landeras-Bueno S, Hsieh L-E, Terada Y, Kim K, Ley K, Shresta S, Saphire EO, Regla-Nava JA (2020) Spiking pandemic potential: structural and immunological aspects of SARSCoV-2. Trends Microbiol 28:605-618

32. Andersen KG, Rambaut A, Lipkin WI, Holmes EC, Garry RF (2020) The proximal origin of SARS-CoV-2. Nat Med 26(4): 450-452

33. Follis KE, York J, Nunberg JH (2006) Furin cleavage of the SARS coronavirus spike glycoprotein enhances cell-cell fusion but does not affect virion entry. Virology 350(2):358-369

34. Bagdonaite I, Wandall HH (2018) Global aspects of viral glycosylation. Glycobiology 28(7):443-467

35. Mänz B, Schwemmle M, Brunotte L (2013) Adaptation of avian influenza a virus polymerase in mammals to overcome the host species barrier. J Virol 87(13):7200-7209

36. Aguas R, Ferguson NM (2013) Feature selection methods for identifying genetic determinants of host species in RNA viruses. PLoS Comput Biol 9(10):e1003254 
37. Tang X, Wu C, Li X, Song Y, Yao X, Wu X, Duan Y, Zhang H, Wang Y, Qian Z, Cui J, Lu J (2020) On the origin and continuing evolution of SARS-CoV-2. Natl Sci Rev 7:1012-1023

38. Gudbjartsson DF, Helgason A, Jonsson H, Magnusson OT, Melsted P, Norddahl GL, Saemundsdottir J, Sigurdsson A, Sulem P, Agustsdottir AB, Eiriksdottir B, Fridriksdottir R, Gardarsdottir EE, Georgsson G, Gretarsdottir OS, Gudmundsson KR, Gunnarsdottir TR, Gylfason A, Holm H, Jensson BO, Jonasdottir A, Jonsson F, Josefsdottir KS, Kristjansson T, Magnusdottir DN, le Roux L, Sigmundsdottir G, Sveinbjornsson G, Sveinsdottir KE, Sveinsdottir M, Thorarensen EA, Thorbjornsson B, Löve A, Masson G, Jonsdottir I, Möller AD, Gudnason T, Kristinsson KG, Thorsteinsdottir U, Stefansson K (2020) Spread of SARS-CoV-2 in the Icelandic population. N Engl J Med 382:2302-2315

39. Hadfield J, Megill C, Bell SM, Huddleston J, Potter B, Callender C, Sagulenko P, Bedford T, Neher RA (2018) Nextstrain: realtime tracking of pathogen evolution. Bioinformatics 34(23):41214123

40. Forster P, Forster L, Renfrew C, Forster M (2020) Phylogenetic network analysis of SARS-CoV-2 genomes. Proc Natl Acad Sci 117(17):9241-9243

41. Brufsky A (2020) Distinct Viral Clades of SARS-CoV-2: Implications for modeling of viral spread. J Med Virol. https:// doi.org/10.1002/jmv. 25902

42. Ontiveros E, Kim TS, Gallagher TM, Perlman S (2003) Enhanced virulence mediated by the murine coronavirus, mouse hepatitis virus strain JHM, is associated with a glycine at residue 310 of the spike glycoprotein. J Virol 77(19):10260-10269

43. Zhu N, Zhang D, Wang W, Li X, Yang B, Song J, Zhao X, Huang B, Shi W, Lu R, Niu P, Zhan F, Ma X, Wang D, Xu W, Wu G, Gao GF, Tan W (2020) A novel coronavirus from patients with pneumonia in China, 2019. N Engl J Med 382(8):727-733

44. Yang P, Wang X (2020) COVID-19: a new challenge for human beings. Cell Mol Immunol 17(5):555-557

45. Hoffmann M, Kleine-Weber H, Schroeder S, Krüger N, Herrler T, Erichsen S, Schiergens TS, Herrler G, Wu N-H, Nitsche A, Müller MA, Drosten C, Pöhlmann S (2020) SARS-CoV-2 cell entry depends on ACE2 and TMPRSS2 and is blocked by a clinically proven protease inhibitor. Cell. 181:271-280.e278

46. Jiang S, Hillyer C, Du L (2020) Neutralizing antibodies against SARS-CoV-2 and other human coronaviruses. Trends Immunol 41:545

47. Walls AC, Park Y-J, Tortorici MA, Wall A, McGuire AT, Veesler D (2020) Structure, function, and antigenicity of the SARS-CoV-2 spike glycoprotein. Cell 181:281-292.e6

48. Guo Y-R, Cao Q-D, Hong Z-S, Tan Y-Y, Chen S-D, Jin H-J, Tan K-S, Wang D-Y, Yan Y (2020) The origin, transmission and clinical therapies on coronavirus disease 2019 (COVID-19) outbreakan update on the status. Mil Med Res 7(1):1-10

49. Schoeman D, Fielding BC (2019) Coronavirus envelope protein: current knowledge. Virol J 16(1):69

50. Tai W, He L, Zhang X, Pu J, Voronin D, Jiang S, Zhou Y, Du L (2020) Characterization of the receptor-binding domain (RBD) of 2019 novel coronavirus: implication for development of RBD protein as a viral attachment inhibitor and vaccine. Cell Mol Immunol:1-8

51. van Doremalen N, Bushmaker T, Morris DH, Holbrook MG, Gamble A, Williamson BN, Tamin A, Harcourt JL, Thornburg NJ, Gerber SI (2020) Aerosol and surface stability of SARSCoV-2 as compared with SARS-CoV-1. N Engl J Med 382(16): $1564-1567$

52. van Doremalen N, Bushmaker T, Morris DH, Holbrook MG, Gamble A, Williamson BN, Tamin A, Harcourt JL, Thornburg NJ, Gerber SI, Lloyd-Smith JO, de Wit E, Munster VJ (2020)
Aerosol and surface stability of SARS-CoV-2 as compared with SARS-CoV-1. N Engl J Med 382(16):1564-1567

53. Santarpia J, Rivera D, Herrera V, Morwitzer M, Creager H, Santarpia G, Crown K, Brett-Major D, Schnaubelt E, Broadhurst M (2020) Transmission potential of SARS-CoV-2 in viral shedding observed at the University of Nebraska Medical Center. MedRxiv.

54. Ong SWX, Tan YK, Chia PY, Lee TH, Ng OT, Wong MSY, Marimuthu K (2020) Air, surface environmental, and personal protective equipment contamination by Severe Acute Respiratory Syndrome Coronavirus 2 (SARS-CoV-2) From a Symptomatic Patient. JAMA 323(16):1610-1612

55. Sungnak W, Huang N, Bécavin C, Berg M, Queen R, Litvinukova M, Talavera-López C, Maatz H, Reichart D, Sampaziotis F, Worlock KB, Yoshida M, Barnes JL, Banovich NE, Barbry P, Brazma A, Collin J, Desai TJ, Duong TE, Eickelberg O, Falk C, Farzan M, Glass I, Gupta RK, Haniffa M, Horvath P, Hubner N, Hung D, Kaminski N, Krasnow M, Kropski JA, Kuhnemund M, Lako M, Lee H, Leroy S, Linnarson S, Lundeberg J, Meyer KB, Miao Z, Misharin AV, Nawijn MC, Nikolic MZ, Noseda M, Ordovas-Montanes J, Oudit GY, Pe'er D, Powell J, Quake S, Rajagopal J, Tata PR, Rawlins EL, Regev A, Reyfman PA, Rozenblatt-Rosen O, Saeb-Parsy K, Samakovlis C, Schiller HB, Schultze JL, Seibold MA, Seidman CE, Seidman JG, Shalek AK, Shepherd D, Spence J, Spira A, Sun X, Teichmann SA, Theis FJ, Tsankov AM, Vallier L, van den Berge M, Whitsett J, Xavier R, Xu Y, Zaragosi L-E, Zerti D, Zhang H, Zhang K, Rojas M, Figueiredo F, Network HCALB (2020) SARS-CoV-2 entry factors are highly expressed in nasal epithelial cells together with innate immune genes. Nat Med 26:681-687

56. Rabi FA, Al Zoubi MS, Kasasbeh GA, Salameh DM, Al-Nasser AD (2020) SARS-CoV-2 and Coronavirus Disease 2019: what we know so far. Pathogens 9(3):231

57. Hamming I, Timens W, Bulthuis ML, Lely AT, Navis G, van Goor H (2004) Tissue distribution of ACE2 protein, the functional receptor for SARS coronavirus. A first step in understanding SARS pathogenesis. J Pathol 203(2):631-637

58. Wang W, Xu Y, Gao R, Lu R, Han K, Wu G, Tan W (2020) Detection of SARS-CoV-2 in different types of clinical specimens. JAMA. https://doi.org/10.1001/jama.2020.3786

59. Wadman M, Couzin-Frankel J, Kaiser J, Matacic C (2020) A rampage through the body. Science 368(6489):356-360

60. Shulla A, Heald-Sargent T, Subramanya G, Zhao J, Perlman S, Gallagher T (2011) A transmembrane serine protease is linked to the severe acute respiratory syndrome coronavirus receptor and activates virus entry. J Virol 85(2):873-882

61. Harrison SC (2015) Viral membrane fusion. Virology 479-480: 498-507

62. de Wilde AH, Snijder EJ, Kikkert M, van Hemert MJ (2018) Host factors in coronavirus replication. Curr Top Microbiol Immunol 419:1-42

63. Hussain S, Pan J, Chen Y, Yang Y, Xu J, Peng Y, Wu Y, Li Z, Zhu Y, Tien P, Guo D (2005) Identification of novel subgenomic RNAs and noncanonical transcription initiation signals of severe acute respiratory syndrome coronavirus. J Virol 79(9):5288-5295

64. V'Kovski P, Gerber M, Kelly J, Pfaender S, Ebert N, Braga Lagache S, Simillion C, Portmann J, Stalder H, Gaschen V, Bruggmann R, Stoffel MH, Heller M, Dijkman R, Thiel V (2019) Determination of host proteins composing the microenvironment of coronavirus replicase complexes by proximity-labeling. Elife 8:e42037

65. Knoops K, Kikkert M, Worm SHE, Zevenhoven-Dobbe JC, van der Meer Y, Koster AJ, Mommaas AM, Snijder EJ (2008) SARScoronavirus replication is supported by a reticulovesicular network of modified endoplasmic reticulum. PLoS Biol 6(9):e226-e226 
66. Stertz S, Reichelt M, Spiegel M, Kuri T, Martínez-Sobrido L, García-Sastre A, Weber F, Kochs G (2007) The intracellular sites of early replication and budding of SARS-coronavirus. Virology 361(2):304-315

67. Kamitani W, Narayanan K, Huang C, Lokugamage K, Ikegami T, Ito N, Kubo H, Makino S (2006) Severe acute respiratory syndrome coronavirus nsp1 protein suppresses host gene expression by promoting host mRNA degradation. Proc Natl Acad Sci 103(34):12885-12890

68. Narayanan K, Huang C, Lokugamage K, Kamitani W, Ikegami T, Tseng C-TK, Makino S (2008) Severe acute respiratory syndrome coronavirus nsp1 suppresses host gene expression, including that of type i interferon, in infected cells. J Virol 82(9):4471-4479

69. Teijaro JR (2016) Type I interferons in viral control and immune regulation. Curr Opin Virol 16:31-40

70. Menachery VD, Debbink K, Baric RS (2014) Coronavirus nonstructural protein 16: evasion, attenuation, and possible treatments. Virus Res 194:191-199

71. Gordon DE, Jang GM, Bouhaddou M, Xu J, Obernier K, White KM, O'Meara MJ, Rezelj VV, Guo JZ, Swaney DL, Tummino TA, Huettenhain R, Kaake RM, Richards AL, Tutuncuoglu B, Foussard H, Batra J, Haas K, Modak M, Kim M, Haas P, Polacco BJ, Braberg H, Fabius JM, Eckhardt M, Soucheray M, Bennett MJ, Cakir M, McGregor MJ, Li Q, Meyer B, Roesch F, Vallet T, Mac Kain A, Miorin L, Moreno E, Naing ZZC, Zhou Y, Peng S, Shi Y, Zhang Z, Shen W, Kirby IT, Melnyk JE, Chorba JS, Lou K, Dai SA, Barrio-Hernandez I, Memon D, HernandezArmenta C, Lyu J, Mathy CJP, Perica T, Pilla KB, Ganesan SJ, Saltzberg DJ, Rakesh R, Liu X, Rosenthal SB, Calviello L, Venkataramanan S, Liboy-Lugo J, Lin Y, Huang X-P, Liu Y, Wankowicz SA, Bohn M, Safari M, Ugur FS, Koh C, Savar NS, Tran QD, Shengjuler D, Fletcher SJ, O'Neal MC, Cai Y, Chang JCJ, Broadhurst DJ, Klippsten S, Sharp PP, Wenzell NA, Kuzuoglu D, Wang H-Y, Trenker R, Young JM, Cavero DA, Hiatt J, Roth TL, Rathore U, Subramanian A, Noack J, Hubert M, Stroud RM, Frankel AD, Rosenberg OS, Verba KA, Agard DA, Ott M, Emerman M, Jura N, von Zastrow M, Verdin E, Ashworth A, Schwartz O, d'Enfert C, Mukherjee S, Jacobson M, Malik HS, Fujimori DG, Ideker T, Craik CS, Floor SN, Fraser JS, Gross JD, Sali A, Roth BL, Ruggero D, Taunton J, Kortemme T, Beltrao P, Vignuzzi M, García-Sastre A, Shokat KM, Shoichet BK, Krogan NJ (2020) A SARS-CoV-2 protein interaction map reveals targets for drug repurposing. Nature. 583:459-468

72. Gordon DE, Jang GM, Bouhaddou M, Xu J, Obernier K, O'meara MJ, Guo JZ, Swaney DL, Tummino TA, Huttenhain R (2020) A SARS-CoV-2-human protein-protein interaction map reveals drug targets and potential drug-repurposing. BioRxiv

73. Astuti I (2020) Severe Acute Respiratory Syndrome Coronavirus 2 (SARS-CoV-2): An overview of viral structure and host response. Diabetes \& Metabolic Syndrome: Clinical Research \& Reviews

74. Neefjes J, Jongsma MLM, Paul P, Bakke O (2011) Towards a systems understanding of MHC class I and MHC class II antigen presentation. Nat Rev Immunol 11(12):823-836

75. Liu J, Wu P, Gao F, Qi J, Kawana-Tachikawa A, Xie J, Vavricka CJ, Iwamoto A, Li T, Gao GF (2010) Novel immunodominant peptide presentation strategy: a featured HLA-A* 2402-restricted cytotoxic T-lymphocyte epitope stabilized by intrachain hydrogen bonds from severe acute respiratory syndrome coronavirus nucleocapsid protein. J Virol 84(22):11849-11857

76. Messaoudi I, Patino JAG, Dyall R, LeMaoult J, Nikolich-Žugich J (2002) Direct link between mhc polymorphism, T cell avidity, and diversity in immune defense. Science 298(5599):1797-1800

77. Cheung Y-K, Cheng SC-S, Sin FW-Y, Chan K-T, Xie Y (2007) Induction of T-cell response by a DNA vaccine encoding a novel
HLA-A* 0201 severe acute respiratory syndrome coronavirus epitope. Vaccine 25(32):6070-6077

78. Wang Y-D, Sin WYF, Xu G-B, Yang H-H, Wong T-Y, Pang XW, He X-Y, Zhang H-G, Ng JNL, Cheng C-SS (2004) T-cell epitopes in severe acute respiratory syndrome (SARS) coronavirus spike protein elicit a specific T-cell immune response in patients who recover from SARS. J Virol 78(11):5612-5618

79. Li T, Xie J, He Y, Fan H, Baril L, Qiu Z, Han Y, Xu W, Zhang W, You H (2006) Long-term persistence of robust antibody and cytotoxic $\mathrm{T}$ cell responses in recovered patients infected with SARS coronavirus. PLoS One 1(1):e24

80. Liu S-J, Leng C-H, S-p L, Chi H-Y, Huang C-Y, Lin C-L, Lian W-C, Chen C-J, Hsieh S-L, Chong P (2006) Immunological characterizations of the nucleocapsid protein based SARS vaccine candidates. Vaccine 24(16):3100-3108

81. Peng H, Yang L-t, Wang L-y, Li J, Huang J, Lu Z-q, Koup RA, Bailer RT, Wu C-y (2006) Long-lived memory T lymphocyte responses against SARS coronavirus nucleocapsid protein in SARS-recovered patients. Virology 351(2):466-475

82. Wang S-F, Chen K-H, Chen M, Li W-Y, Chen Y-J, Tsao C-H, My Y, Huang JC, Chen Y-MA (2011) Human-leukocyte antigen class I CW 1502 and class II DR 0301 genotypes are associated with resistance to severe acute respiratory syndrome (SARS) infection. Viral Immunol 24(5):421-426

83. Keicho N, Itoyama S, Kashiwase K, Phi NC, Long HT, Van Ban V, Hoa BK, Le Hang NT, Hijikata M, Sakurada S (2009) Association of human leukocyte antigen class II alleles with severe acute respiratory syndrome in the Vietnamese population. Hum Immunol 70(7):527-531

84. Lin M, Tseng H-K, Trejaut JA, Lee H-L, Loo J-H, Chu C-C, Chen P-J, Su Y-W, Lim KH, Tsai Z-U (2003) Association of HLA class I with severe acute respiratory syndrome coronavirus infection. BMC Med Genet 4(1):9

85. Ng MH, Lau K-M, Li L, Cheng S-H, Chan WY, Hui PK, Zee B, Leung C-B, Sung JJ (2004) Association of human-leukocyteantigen class I (B* 0703) and class II (DRB1* 0301) genotypes with susceptibility and resistance to the development of severe acute respiratory syndrome. J Infect Dis 190(3):515-518

86. Hajeer AH, Balkhy H, Johani S, Yousef MZ, Arabi Y (2016) Association of human leukocyte antigen class II alleles with severe Middle East respiratory syndrome-coronavirus infection. Ann Thorac Med 11(3):211-213

87. Nguyen A, David JK, Maden SK, Wood MA, Weeder BR, Nellore A, Thompson RF (2020) Human leukocyte antigen susceptibility map for SARS-CoV-2. J Virol:00510-00520. https:// doi.org/10.1128/jvi.00510-20

88. Kiyotani K, Toyoshima Y, Nemoto K, Nakamura Y (2020) Bioinformatic prediction of potential $\mathrm{T}$ cell epitopes for SARSCov-2. J Hum Genet:1-7

89. Li G, Fan Y, Lai Y, Han T, Li Z, Zhou P, Pan P, Wang W, Hu D, Liu $X$ (2020) Coronavirus infections and immune responses. J Med Virol 92(4):424-432

90. Sungnak W, Huang N, Bécavin C, Berg M, Queen R, Litvinukova M, Talavera-López C, Maatz H, Reichart D, Sampaziotis F (2020) SARS-CoV-2 entry factors are highly expressed in nasal epithelial cells together with innate immune genes. Nat Med:1-7

91. Wang C, Li W, Drabek D, Okba NMA, van Haperen R, Osterhaus ADME, van Kuppeveld FJM, Haagmans BL, Grosveld F, Bosch B-J (2020) A human monoclonal antibody blocking SARS-CoV-2 infection. Nat Commun 11(1):2251

92. Cao Y, Su B, Guo X, Sun W, Deng Y, Bao L, Zhu Q, Zhang X, Zheng Y, Geng C (2020) Potent neutralizing antibodies against SARS-CoV-2 identified by high-throughput single-cell sequencing of convalescent patients' B cells. Cell 182:73-84.e16

93. Ju B, Zhang Q, Ge X, Wang R, Yu J, Shan S, Zhou B, Song S, Tang X, Yu J, Ge J, Lan J, Yuan J, Wang H, Zhao J, Zhang S, 
Wang Y, Shi X, Liu L, Wang X, Zhang Z, Zhang L (2020) Potent human neutralizing antibodies elicited by SARS-CoV-2 infection. bioRxiv:2020.2003.2021.990770. https://doi.org/10.1101/2020. 03.21.990770

94. Wang C, Li W, Drabek D, Okba NM, van Haperen R, Osterhaus AD, van Kuppeveld FJ, Haagmans BL, Grosveld F, Bosch B-J (2020) A human monoclonal 1 antibody blocking SARS-CoV-2 infection. Biorxiv

95. Tino M, Wright J (1996) Surfactant protein A stimulates phagocytosis of specific pulmonary pathogens by alveolar macrophages. Am J Phys Lung Cell Mol Phys 270(4):L677-L688

96. Watford WT, Smithers MB, Frank MM, Wright JR (2002) Surfactant protein A enhances the phagocytosis of C1q-coated particles by alveolar macrophages. Am J Phys Lung Cell Mol Phys 283(5):L1011-L1022

97. Sallard E, Lescure F-X, Yazdanpanah Y, Mentre F, PeifferSmadja N (2020) Type 1 interferons as a potential treatment against COVID-19. Antivir Res 178:104791

98. Sajuthi SP, DeFord P, Jackson ND, Montgomery MT, Everman JL, Rios CL, Pruesse E, Nolin JD, Plender EG, Wechsler ME (2020) Type 2 and interferon inflammation strongly regulate SARS-CoV-2 related gene expression in the airway epithelium. bioRxiv

99. Swann JB, Hayakawa Y, Zerafa N, Sheehan KCF, Scott B, Schreiber RD, Hertzog P, Smyth MJ (2007) Type I IFN contributes to NK cell homeostasis, activation, and antitumor function. $\mathrm{J}$ Immunol 178(12):7540-7549

100. Kohlmeier JE, Cookenham T, Roberts AD, Miller SC, Woodland DL (2010) Type I interferons regulate cytolytic activity of memory CD8(+) T cells in the lung airways during respiratory virus challenge. Immunity 33(1):96-105

101. Liao M, Liu Y, Yuan J, Wen Y, Xu G, Zhao J, Cheng L, Li J, Wang X, Wang F, Liu L, Amit I, Zhang S, Zhang Z (2020) Singlecell landscape of bronchoalveolar immune cells in patients with COVID-19. Nat Med 26:842-844

102. Rothan HA, Byrareddy SN (2020) The epidemiology and pathogenesis of coronavirus disease (COVID-19) outbreak. J Autoimmun 109:102433

103. Liu Y, Yan L-M, Wan L, Xiang T-X, Le A, Liu J-M, Peiris M, Poon LL, Zhang W (2020) Viral dynamics in mild and severe cases of COVID-19. Lancet Infect Dis

104. Lauer SA, Grantz KH, Bi Q, Jones FK, Zheng Q, Meredith HR, Azman AS, Reich NG, Lessler J (2020) The incubation period of coronavirus disease 2019 (COVID-19) from publicly reported confirmed cases: estimation and application. Ann Intern Med 172(9):577-582

105. Hussell T, Bell TJ (2014) Alveolar macrophages: plasticity in a tissue-specific context. Nat Rev Immunol 14(2):81-93

106. Gwyer Findlay E, Hussell T (2012) Macrophage-mediated inflammation and disease: a focus on the lung. Mediat Inflamm:2012

107. Herold S, Mayer K, Lohmeyer J (2011) Acute lung injury: how macrophages orchestrate resolution of inflammation and tissue repair. Front Immunol 2:65

108. Evren E, Ringqvist E, Willinger T (2019) Origin and ontogeny of lung macrophages: from mice to humans. Immunology

109. Tay MZ, Poh CM, Rénia L, MacAry PA, Ng LFP (2020) The trinity of COVID-19: immunity, inflammation and intervention. Nat Rev Immunol 20:363-374

110. Huang C, Wang Y, Li X, Ren L, Zhao J, Hu Y, Zhang L, Fan G, Xu J, Gu X (2020) Clinical features of patients infected with 2019 novel coronavirus in Wuhan, China. Lancet 395(10223):497-506

111. Wu F, Zhao S, Yu B, Chen Y-M, Wang W, Song Z-G, Hu Y, Tao Z-W, Tian J-H, Pei Y-Y (2020) A new coronavirus associated with human respiratory disease in China. Nature 579(7798):265269
112. Hotez PJ, Corry DB, Bottazzi ME (2020) COVID-19 vaccine design: the Janus face of immune enhancement. Nat Rev Immunol 20:347-348

113. Iwasaki A, Yang Y (2020) The potential danger of suboptimal antibody responses in COVID-19. Nat Rev Immunol 20:339-341

114. Peiris JSM, Gordon S, Unkeless JC, Porterfield JS (1981) Monoclonal anti-Fc receptor IgG blocks antibody enhancement of viral replication in macrophages. Nature 289(5794):189-191

115. Pan Y, Zhang D, Yang P, Poon LL, Wang Q (2020) Viral load of SARS-CoV-2 in clinical samples. Lancet Infect Dis 20(4):411412

116. Zhang W, Zhao Y, Zhang F, Wang Q, Li T, Liu Z, Wang J, Qin Y, Zhang X, Yan X, Zeng X, Zhang S (2020) The use of antiinflammatory drugs in the treatment of people with severe coronavirus disease 2019 (COVID-19): The perspectives of clinical immunologists from China. Clin Immunol 214:108393

117. Conti P, Ronconi G, Caraffa A, Gallenga CE, Ross R, Frydas I, Kritas SK (2020) Induction of pro-inflammatory cytokines (IL-1 and IL-6) and lung inflammation by Coronavirus-19 (COVI-19 or SARS-CoV-2): anti-inflammatory strategies. J Biol Regul Homeost Agents 34(2). https://doi.org/10.23812/conti-e

118. Pacha O, Sallman MA, Evans SE (2020) COVID-19: a case for inhibiting IL-17? Nat Rev Immunol 20:345-346

119. Kuri-Cervantes L, Pampena MB, Meng W, Rosenfeld AM, Ittner CAG, Weisman AR, Agyekum RS, Mathew D, Baxter AE, Vella LA, Kuthuru O, Apostolidis SA, Bershaw L, Dougherty J, Greenplate AR, Pattekar A, Kim J, Han N, Gouma S, Weirick ME, Arevalo CP, Bolton MJ, Goodwin EC, Anderson EM, Hensley SE, Jones TK, Mangalmurti NS, Luning Prak ET, Wherry EJ, Meyer NJ, Betts MR (2020) Comprehensive mapping of immune perturbations associated with severe COVID-19. Sci Immunol 5(49):eabd7114

120. Giamarellos-Bourboulis EJ, Netea MG, Rovina N, Akinosoglou K, Antoniadou A, Antonakos N, Damoraki G, Gkavogianni T, Adami M-E, Katsaounou P (2020) Complex immune dysregulation in COVID-19 patients with severe respiratory failure. Cell Host Microbe 27:992-1000.e3

121. Weiskopf D, Schmitz KS, Raadsen MP, Grifoni A, Okba NM, Endeman H, van den Akker JP, Molenkamp R, Koopmans MP, van Gorp EC (2020) Phenotype of SARS-CoV-2-specific T-cells in COVID-19 patients with acute respiratory distress syndrome. medRxiv

122. Zheng H-Y, Zhang M, Yang C-X, Zhang N, Wang X-C, Yang XP, Dong X-Q, Zheng Y-T (2020) Elevated exhaustion levels and reduced functional diversity of $\mathrm{T}$ cells in peripheral blood may predict severe progression in COVID-19 patients. Cell Mol Immunol 17(5):541-543

123. Gao T, Hu M, Zhang X, Li H, Zhu L, Liu H, Dong Q, Zhang Z, Wang Z, Hu Y, Fu Y, Jin Y, Li K, Zhao S, Xiao Y, Luo S, Li L, Zhao L, Liu J, Zhao H, Liu Y, Yang W, Peng J, Chen X, Li P, Liu Y, Xie Y, Song J, Zhang L, Ma Q, Bian X, Chen W, Liu X, Mao Q, Cao C (2020) Highly pathogenic coronavirus N protein aggravates lung injury by MASP-2-mediated complement over-activation. medRxiv:2020.2003.2029.20041962. https://doi.org/10. $1101 / 2020.03 .29 .20041962$

124. Guo R-F, Ward PA (2005) Role of C5A in inflammatory responses. Annu Rev Immunol 23(1):821-852

125. Jose RJ, Manuel A (2020) COVID-19 cytokine storm: the interplay between inflammation and coagulation. Lancet Respir Med

126. Girija ASS, Shankar EM, Larsson M (2020) Could SARS-CoV-2induced hyperinflammation magnify the severity of coronavirus disease (CoViD-19) leading to acute respiratory distress syndrome? Front Immunol 11(1206). https://doi.org/10.3389/fimmu. 2020.01206

127. Tian S, Hu W, Niu L, Liu H, Xu H, Xiao S-Y (2020) Pulmonary pathology of early phase 2019 novel coronavirus (COVID-19) 
pneumonia in two patients with lung cancer. J Thorac Oncol 15: 700-704

128. Tang N, Bai H, Chen X, Gong J, Li D, Sun Z (2020) Anticoagulant treatment is associated with decreased mortality in severe coronavirus disease 2019 patients with coagulopathy. J Thromb Haemost 18(5):1094-1099

129. Fox SE, Akmatbekov A, Harbert JL, Li G, Brown JQ, Vander Heide RS (2020) Pulmonary and cardiac pathology in Covid-19: the first autopsy series from New Orleans. MedRxiv

130. Xu Y-H, Dong J-H, An W-M, Lv X-Y, Yin X-P, Zhang J-Z, Dong L, Ma X, Zhang H-J, Gao B-L (2020) Clinical and computed tomographic imaging features of novel coronavirus pneumonia caused by SARS-CoV-2. J Infect 80(4):394-400

131. Poyiadji N, Shahin G, Noujaim D, Stone M, Patel S, Griffith B COVID-19-associated acute hemorrhagic necrotizing encephalopathy: CT and MRI features. Radiology 0(0):201187

132. Asadi-Pooya AA, Simani L (2020) Central nervous system manifestations of COVID-19: a systematic review. J Neurol Sci 413: 116832

133. Zhang T, Sun LX, Feng RE (2020) Comparison of clinical and pathological features between severe acute respiratory syndrome and coronavirus disease 2019. Zhonghua Jie He He Hu Xi Za Zhi 43(0):E040

134. Feng Z, Diao B, Wang R, Wang G, Wang C, Tan Y, Liu L, Wang C, Liu Y, Liu Y (2020) The novel severe acute respiratory syndrome coronavirus 2 (SARS-CoV-2) directly decimates human spleens and lymph nodes. medRxiv

135. Wadman M, Couzin-Frankel J, Kaiser J, Matacic C (2020) A rampage through the body. American Association for the Advancement of Science

136. Qi F, Qian S, Zhang S, Zhang Z (2020) Single cell RNA sequencing of 13 human tissues identify cell types and receptors of human coronaviruses. Biochem Biophys Res Commun 526(1):135-140

137. Chen Y, Feng Z, Diao B, Wang R, Wang G, Wang C, Tan Y, Liu L, Wang C, Liu Y, Liu Y, Yuan Z, Ren L, Wu Y (2020) The novel severe acute respiratory syndrome coronavirus 2 (SARS-CoV-2) directly decimates human spleens and lymph nodes. medRxiv: 2020.2003.2027.20045427. https://doi.org/10.1101/2020.03.27. 20045427

138. Gnanadhas DP, Dash PK, Sillman B, Bade AN, Lin Z, Palandri DL, Gautam N, Alnouti Y, Gelbard HA, McMillan J, Mosley RL, Edagwa B, Gendelman HE, Gorantla S (2017) Autophagy facilitates macrophage depots of sustained-release nanoformulated antiretroviral drugs. J Clin Invest 127(3):857-873

139. Herskovitz J, Gendelman HE (2019) HIV and the macrophage: from cell reservoirs to drug delivery to viral eradication. J NeuroImmune Pharmacol 14(1):52-67

140. Dash PK, Kaminski R, Bella R, Su H, Mathews S, Ahooyi TM, Chen C, Mancuso P, Sariyer R, Ferrante P, Donadoni M, Robinson JA, Sillman B, Lin Z, Hilaire JR, Banoub M, Elango M, Gautam N, Mosley RL, Poluektova LY, McMillan J, Bade AN, Gorantla S, Sariyer IK, Burdo TH, Young W-B, Amini S, Gordon J, Jacobson JM, Edagwa B, Khalili K, Gendelman HE (2019) Sequential LASER ART and CRISPR treatments eliminate HIV-1 in a subset of infected humanized mice. Nat Commun 10(1):2753-2753

141. Berthelot J-M, Lioté F (2020) COVID-19 as a STING disorder with delayed over-secretion of interferon-beta. EBioMedicine 56: 102801-102801

142. Sun L, Xing Y, Chen X, Zheng Y, Yang Y, Nichols DB, Clementz MA, Banach BS, Li K, Baker SC, Chen Z (2012) Coronavirus papain-like proteases negatively regulate antiviral innate immune response through disruption of STING-mediated signaling. PLoS One 7(2):e30802-e30802

143. Chen X, Yang X, Zheng Y, Yang Y, Xing Y, Chen Z (2014) SARS coronavirus papain-like protease inhibits the type I interferon signaling pathway through interaction with the STINGTRAF3-TBK1 complex. Protein Cell 5(5):369-381

144. Cui J, Han N, Streicker D, Li G, Tang X, Shi Z, Hu Z, Zhao G, Fontanet A, Guan Y, Wang L, Jones G, Field HE, Daszak P, Zhang S (2007) Evolutionary relationships between bat coronaviruses and their hosts. Emerg Infect Dis 13(10):15261532

145. Xie J, Li Y, Shen X, Goh G, Zhu Y, Cui J, Wang L-F, Shi Z-L, Zhou P (2018) Dampened STING-dependent interferon activation in bats. Cell Host Microbe 23(3):297-301. e294

146. Adam D (2020) Special report: the simulations driving the world's response to COVID-19. Nature 580:316-318

147. Korber B, Fischer WM, Gnanakaran S, Yoon H, Theiler J, Abfalterer W, Hengartner N, Giorgi EE, Bhattacharya T, Foley B, Hastie KM, Parker MD, Partridge DG, Evans CM, Freeman TM, de Silva TI, Sheffield C-GG, McDanal C, Perez LG, Tang H, Moon-Walker A, Whelan SP, LaBranche CC, Saphire EO, Montefiori DC (2020) Tracking changes in SARS-CoV-2 spike: evidence that $\mathrm{D} 614 \mathrm{G}$ increases infectivity of the COVID-19 virus. Cell:S0092-8674(0020)30820-30825. https://doi.org/10.1016/j. cell.2020.06.043

148. Casadevall A, Pirofski L (2001) Host-pathogen interactions: the attributes of virulence. J Infect Dis 184(3):337-344

149. Kupferschmidt K (2020) The pandemic virus is slowly mutating. But does it matter? American Association for the Advancement of Science

150. Liu Y, Bi L, Chen Y, Wang Y, Fleming J, Yu Y, Gu Y, Liu C, Fan L, Wang X, Cheng M (2020) Active or latent tuberculosis increases susceptibility to COVID-19 and disease severity. medRxiv:2020.2003.2010.20033795. https://doi.org/10.1101/ 2020.03.10.20033795

151. Harries A, Martinez L, Chakaya J (2020) Monitoring the COVID19 pandemic in sub-Saharan Africa: focusing on health facility admissions and deaths. Int J Tuberc Lung Dis 27

152. Adepoju P (2020) Tuberculosis and HIV responses threatened by COVID-19. The Lancet HIV

153. Yancy CW (2020) COVID-19 and African Americans. JAMA. 323:1891

154. Kapata N, Ihekweazu C, Ntoumi F, Raji T, Chanda-Kapata P, Mwaba P, Mukonka V, Bates M, Tembo J, Corman V (2020) Is Africa prepared for tackling the COVID-19 (SARS-CoV-2) epidemic. Lessons from past outbreaks, ongoing pan-African public health efforts, and implications for the future. Int J Infect Dis 93: 233-236

155. Barbarossa MV, Röst G (2015) Immuno-epidemiology of a population structured by immune status: a mathematical study of waning immunity and immune system boosting. J Math Biol 71(6-7): $1737-1770$

156. Barbarossa MV, Polner M, Rost G (2017) Stability switches induced by immune system boosting in an SIRS model with discrete and distributed delays. SIAM J Appl Math 77(3):905-923

Publisher's note Springer Nature remains neutral with regard to jurisdictional claims in published maps and institutional affiliations. 